\title{
CHLORINE-36 IN WATER, SNOW, AND MID-LATITUDE GLACIAL ICE OF NORTH AMERICA: METEORIC AND WEAPONS-TESTS PRODUCTION IN THE VICINITY OF THE IDAHO NATIONAL ENGINEERING AND ENVIRONMENTAL LABORATORY, IDAHO
}

U.S. GEOLOGICAL SURVEY

Water Resources Investigations Report 99-4037

Prepared in cooperation with the U.S. DEPARTMENT OF ENERGY

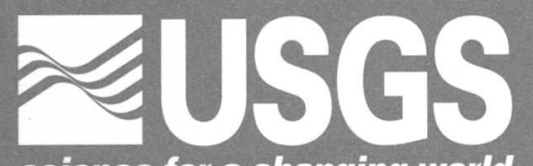


Cover: The Upper Fremont Glacier, Wind River Range, Wyoming, courtesy of Flint Hall, State of Idaho INEEL Oversight Program. Photograph taken from the Lower Fremont Glacier. 


\section{CHLORINE-36 IN WATER, SNOW, AND MID-LATITUDE GLACIAL ICE OF NORTH AMERICA: METEORIC AND WEAPONS-TESTS PRODUCTION IN THE VICINITY OF THE IDAHO NATIONAL ENGINEERING AND ENVIRONMENTAL LABORATORY, IDAHO}

By L. DeWayne Cecil and Jaromy R. Green, U.S. Geological Survey, Idaho Falls, Idaho;

Stephan Vogt, Purdue University, West Lafayette, Indiana;

Shaun K. Frape, University of Waterloo, Ontario, Canada;

Stanley N. Davis, University of Arizona, Tucson, Arizona;

Gary L. Cottrell, U.S. Geological Survey, Arvada, Colorado; and

Pankaj Sharma, Purdue University, West Lafayette, Indiana

U.S. GEOLOGICAL SURVEY

Water Resources Investigations Report 99-4037

Prepared in cooperation with the U.S. DEPARTMENT OF ENERGY

Idaho Falls, Idaho 


\title{
U.S. DEPARTMENT OF THE INTERIOR \\ BRUCE BABBITT, Secretary
}

\author{
U.S. GEOLOGICAL SURVEY \\ Charles G. Groat, Director
}

Any use of trade, product, or firm names in this publication is for descriptive purposes only and does not constitute endorsement by the U.S. Government.

For additional information write to:

U.S. Geological Survey

INEEL, MS 4148

Idaho Falls, ID 83403-2230
Copies of this report can be purchased from:

U.S. Geological Survey

Information Services

Box 25286, Denver Federal Center

Denver, CO 80225-0046 


\section{CONTENTS}

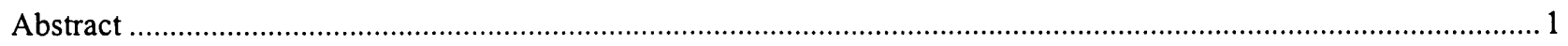

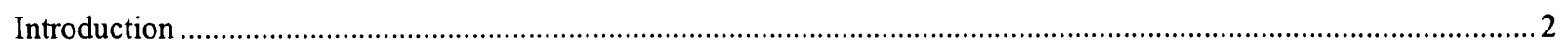

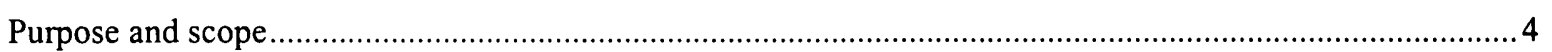

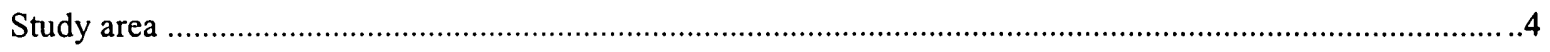

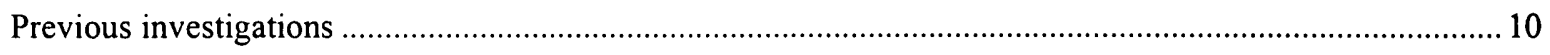

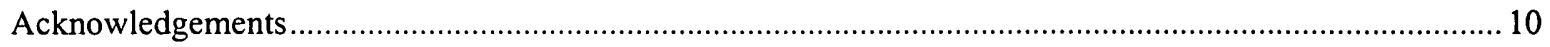

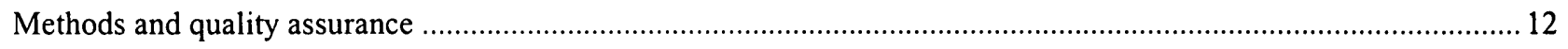

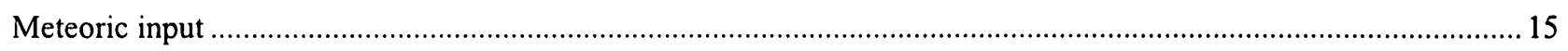

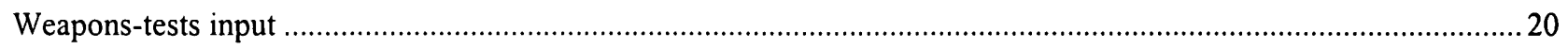

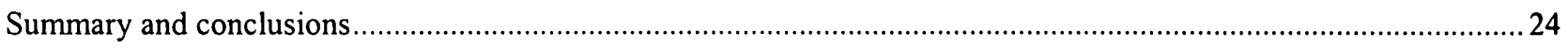

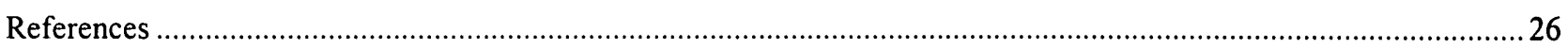

\section{ILLUSTRATIONS}

1. Map showing location of the Idaho National Engineering and Environmental Laboratory and selected ground-water,

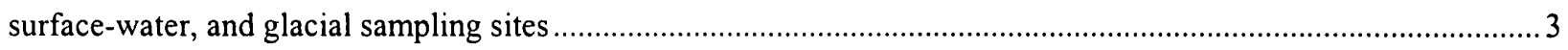

2. Map showing location of the eastern Snake River Plain, the Idaho National Engineering and Environmental Laboratory, selected facilities, and sampling sites for surface water and snow....................................................... 7

3. Graph showing comparison of ${ }^{36} \mathrm{Cl}$ fallout and tritium fallout in the Northern and Southern Hemispheres ................9

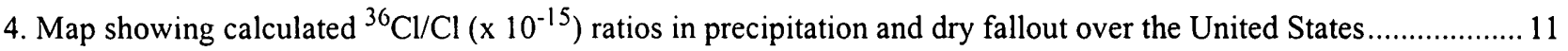

5. Graph showing mechanisms that can change ${ }^{36} \mathrm{Cl}$ concentrations and (or) ${ }^{36} \mathrm{Cl} / \mathrm{Cl}$ ratios .................................... 16

6. Graph showing chlorine- 36 concentrations in water, snow, and glacial-runoff samples ......................................... 18

7. Graph showing chlorine-36 in glacial-ice samples, Upper Fremont Glacier, Wind River Range, Wyoming .............21

8. Graph showing comparison of dissolved-chloride concentration in annual ice layers with the annual-weighted dissolved-chloride concentration at the National Atmospheric Deposition Program station near Pinedale, Wyoming.

\section{TABLES}

1. Dissolved-chloride concentration, amount of ${ }^{36} \mathrm{Cl}$-free chloride carrier added, ${ }^{36} \mathrm{Cl}$ concentration and calculated fluxes in surface-water, ground-water, spring, snow, and glacial-runoff samples

2. Dissolved-chloride concentration, amount of ${ }^{36} \mathrm{Cl}$-free chloride carrier added, ${ }^{36} \mathrm{Cl}$ concentration and calculated fluxes in samples from ice core collected in the summer of 1991 from the Upper Fremont Glacier, Wyoming .......... 8

3. Dissolved-chloride concentration, amount of ${ }^{36} \mathrm{Cl}$-free chloride carrier added, and measured ${ }^{36} \mathrm{Cl} / \mathrm{Cl}$ in quality-assurance samples

4. Mass ratios of chloride/bromide for selected surface-water samples and a glacial-runoff sample. 


\section{CONVERSION FACTORS, VERTICAL DATUM, AND ABBREVIATED UNITS}

Multiply

meter $(\mathrm{m})$

kilometer $(\mathrm{km})$

square kilometer $\left(\mathrm{km}^{2}\right)$

liter (L)

kilogram (kg)

degree Celsius $\left({ }^{\circ} \mathrm{C}\right)$
By

3.281

0.622

0.386

0.264

2.204

$\left({ }^{\circ} \mathrm{C}(9 / 5)\right)+32$
To obtain

foot

mile

square mile

gallon

pound

degree Fahrenheit $\left({ }^{\circ} \mathrm{F}\right)$

Sea Level: In this report, "sea level" refers to the National Geodetic Vertical Datum of 1929-a geodetic datum derived from a general adjustment of the first-order level nets of both the United States and Canada, formerly called Sea Level Datum of 1929.

Abbreviated units used in report: $\mathrm{mg} / \mathrm{L}$ (milligrams per liter); atoms/L (atoms per liter); $\mathrm{m}$ (meters); atoms $/ \mathrm{cm}^{2} \mathrm{sec}$ (atoms per squarecentimeter per second); atoms $/ \mathrm{g}$ (atoms per gram); $\mathrm{g} / \mathrm{cm}^{2} \mathrm{yr}$ (grams per square centimeter per year); $\mathrm{g}$ (grams); $\mathrm{m} / \mathrm{km}(\mathrm{meters} \mathrm{per} \mathrm{kilo-}$ meter); $\mathrm{m}^{2} /$ day (square meters per day); $\mathrm{cm} / \mathrm{yr}$ (centimeters per year); $\mu \mathrm{m}$ (micrometer); $\mu \mathrm{L}$ (microliters); mm (millimeters), $\mathrm{mL}$ (milliliters); mM (millimolar); M (Molar); megohms-cm, (megohms centimeter). 


\title{
CHLORINE-36 IN WATER, SNOW, AND MID-LATITUDE GLACIAL ICE OF NORTH AMERICA: METEORIC AND WEAPONS-TESTS PRODUCTION IN THE VICINITY OF THE IDAHO NATIONAL ENGINEERING AND ENVIRONMENTAL LABORATORY, IDAHO
}

\author{
By L. DeWayne Cecil and Jaromy R. Green, U.S. Geological Survey, Idaho Falls, \\ Idaho; \\ Stephan Vogt, Purdue University, West Lafayette, Indiana; \\ Shaun K. Frape, University of Waterloo, Ontario, Canada; \\ Stanley N. Davis, University of Arizona, Tucson, Arizona; \\ Gary L. Cottrell, U.S. Geological Survey, Arvada, Colorado; and \\ Pankaj Sharma, Purdue University, West Lafayette, Indiana
}

\section{Abstract}

Measurements of chlorine-36 $\left({ }^{36} \mathrm{Cl}\right)$ were made for 64 water, snow, and glacial-ice and -runoff samples to determine the meteoric and weaponstests-produced concentrations and fluxes of this radionuclide at mid-latitudes in North America. The results will facilitate the use of ${ }^{36} \mathrm{Cl}$ as a hydrogeologic tracer at the Idaho National Engineering and Environmental Laboratory (INEEL). This information was used to estimate meteoric and weapons-tests contributions of this nuclide to environmental inventories at and near the INEEL. Eighteen surface-water samples from six sites were selected from the U.S. Geological Survey's (USGS) archive-sample library at the INEEL for ${ }^{36} \mathrm{Cl}$ analyses. These 18 samples had been collected during $1969-94 ;{ }^{36} \mathrm{Cl}$ concentrations ranged from $0.2 \pm 0.02 \times 10^{8}$ to $2.2 \pm 0.05 \times 10^{8}$ atoms/liter (atoms/L). In 1994-95, an additional 14 surface-water and 2 spring samples from the eastern Snake River Plain were collected and analyzed for ${ }^{36} \mathrm{Cl} ;{ }^{36} \mathrm{Cl}$ concentrations ranged from $0.014 \pm 0.001$ $\times 10^{8}$ to $6.2 \pm 0.7 \times 10^{8}$ atoms $/ \mathrm{L}$, a range similar to the range of concentrations in the 18 archived samples. For comparison, ${ }^{36} \mathrm{Cl}$ concentrations in water from two monitoring wells at the INEEL were as large as $0.06 \pm 0.003 \times 10^{8}$ atoms $/ \mathrm{L}$ for the well (Site 14) not affected by site waste disposal and $19,000 \pm 914 \times 10^{8}$ atoms/L for the well (USGS 77) about 500 meters $(\mathrm{m})$ hydraulically downgradient from the Idaho Nuclear Technology and Engineering Center (INTEC).
Four snow samples were collected in 1991 at and near the INEEL to aid in establishing meteoric concentrations. The detectable ${ }^{36} \mathrm{Cl}$ concentrations in the snow samples ranged nearly four orders of magnitude, from $6.3 \pm 0.9 \times 10^{6}$ atoms $/ \mathrm{L}$ at Harriman State Park, 150 kilometers $(\mathrm{km})$ northeast of the INEEL, to $1.7 \pm 0.3 \times 10^{10}$ atoms $/ \mathrm{L}$ near the INTEC. The estimated ${ }^{36} \mathrm{Cl}$ flux for a sample collected in Harriman State Park was $1.2 \pm 0.2 \times 10^{-2}$ atoms/square centimeter/second (atoms $/ \mathrm{cm}^{2} \mathrm{sec}$ ). The estimated ${ }^{36} \mathrm{Cl}$ flux for a sample collected in Copper Basin, $75 \mathrm{~km}$ west of the INEEL, was $3 \pm 2 \times 10^{-3}$ atoms $/ \mathrm{cm}^{2} \mathrm{sec}$. For comparison, 2 snow samples were collected at the INEEL downwind from the INTEC during nuclear-waste calcining operations. The estimated ${ }^{36} \mathrm{Cl}$ flux for the sample collected $11 \mathrm{~km}$ southwest of the effluent stack at the INTEC was $1.0 \pm 0.03$ atoms $/ \mathrm{cm}^{2} \mathrm{sec}$ and for the sample $1.5 \mathrm{~km}$ downwind, the flux was $12.0 \pm 2.4$ atoms $/ \mathrm{cm}^{2} \mathrm{sec}$.

A $160-\mathrm{m}$ ice core was collected in 1991 from the Upper Fremont Glacier in the Wind River Range of Wyoming in the western United States. In 1994-95, ice from this core was processed at the National Ice Core Laboratory in Denver, Colorado, and analyzed for ${ }^{36} \mathrm{Cl}$. A tritium weapons-tests peak identified in the ice core was used as a marker to estimate the depth of weapons-tests produced ${ }^{36} \mathrm{Cl}$. Tritium concentrations ranged from 0 tritium units for older ice to more than 360 tritium units at $29 \mathrm{~m}$ below the surface of the glacier, a depth that includes ice that was deposited as 
snow during nuclear-weapons tests through the early 1960 's. Maximum ${ }^{36} \mathrm{Cl}$ production during nuclear-weapons tests was in the late 1950's; therefore, analyses were performed on ice samples from depths of 29.8 to $35.3 \mathrm{~m}$. The peak ${ }^{36} \mathrm{Cl}$ concentration in these samples was $7.7 \pm 0.2 \times 10^{7}$ atoms $/ \mathrm{L}$ at a depth of about $32 \mathrm{~m}$. Estimated flux for ${ }^{36} \mathrm{Cl}$ in ice deposited as snow in the 1950's ranged from $9.0 \pm 0.2 \times 10^{-2}$ atoms $/ \mathrm{cm}^{2} \mathrm{sec}$ for an ice sample from 34.2 to $34.8 \mathrm{~m}$ to $2.9 \pm 0.1 \times 10^{-1}$ atoms $/ \mathrm{cm}^{2} \mathrm{sec}$ for an ice sample from 31.5 to 32.0 $\mathrm{m}$; a mean global natural-production flux for ${ }^{36} \mathrm{Cl}$ of $1.1 \times 10^{-3}$ atoms $/ \mathrm{cm}^{2} \mathrm{sec}$ has been reported. The peak ${ }^{36} \mathrm{Cl}$ flux calculated in the present study was two orders of magnitude larger than the mean global natural-production flux and was similar to the weapons-tests flux of $5 \times 10^{-1}$ atoms $/ \mathrm{cm}^{2} \mathrm{sec}$ reported for the Dye 3 ice core from Greenland which was deposited during the same period of time as the Upper Fremont Glacier ice.

Ice samples from depths of 19.6 to $25.0 \mathrm{~m}, 39.6$ to $46.4 \mathrm{~m}$, and 104.7 to $106.3 \mathrm{~m}$ were selected to represent pre- and post-weapons-tests ${ }^{36} \mathrm{Cl}$ concentrations and fluxes. The ${ }^{36} \mathrm{Cl}$ concentrations in the pre- and post-weapons sections of glacial ice and runoff were less than $2 \times 10^{7}$ atoms $/ \mathrm{L}$. The estimated fluxes from these cores ranged from $4.5 \pm 0.7$ $\times 10^{-3}$ atoms $/ \mathrm{cm}^{2} \mathrm{sec}$ to $6.3 \pm 0.3 \times 10^{-2}$ atoms $/ \mathrm{cm}^{2} \mathrm{sec}$. For comparison, a glacial-runoff sample collected in 1995 at Galena Creek Rock Glacier, $180 \mathrm{~km}$ north of the Upper Fremont Glacier, had an estimated concentration of $3.2 \pm 0.5 \times$ $10^{6}$ atoms $/ \mathrm{L}$ and an estimated flux of $1.6 \pm 0.2 \times$ $10^{-2}$ atoms $/ \mathrm{cm}^{2} \mathrm{sec}$.

The data presented in this report suggest a meteoric source of ${ }^{36} \mathrm{Cl}$ for environmental samples collected in southeastern Idaho and western Wyoming if the concentration is less than $1 \times 10^{7}$ atoms/L. Additionally, concentrations in water, snow, or glacial ice between $1 \times 10^{7}$ and $1 \times 10^{8}$ atoms $/ \mathrm{L}$ may be indicative of a weapons-tests component from peak ${ }^{36} \mathrm{Cl}$ production in the late 1950s. Chlorine- 36 concentrations between $1 \times$ $10^{8}$ and $1 \times 10^{9}$ atoms $/ \mathrm{L}$ may be representative of re-suspension of weapons-tests fallout, airborne disposal of ${ }^{36} \mathrm{Cl}$ from the INTEC, or evapotranspiration.
It was concluded from the water, snow, and glacial data presented here that concentrations of ${ }^{36} \mathrm{Cl}$ measured in environmental samples at the INEEL larger than $1 \times 10^{9}$ atoms $/ \mathrm{L}$ can be attributed to waste-disposal practices.

\section{INTRODUCTION}

Radioactive chlorine-36 $\left({ }^{36} \mathrm{Cl}\right)$ has a half-life of 301,000 years and decays by beta-particle emission (Parrington and others, 1996). Releases of ${ }^{36} \mathrm{Cl}$ to the environment at the Idaho National Engineering and Environmental Laboratory (INEEL) (fig. 1) as a result of nuclear-waste processing operations, have been well documented (Cecil and others, 1992; Beasley and others, 1993). This ${ }^{36} \mathrm{Cl}$ was produced by neutron activation of stable chlorine- $35\left({ }^{35} \mathrm{Cl}\right)$ present as impurities in nuclear-fuel bundles, reactor-cooling water, and other process wastes. Radioactive chlorine then is released to the environment in liquid and gaseous effluents as chlorine gas and/or nitrosyl chloride by the following reaction:

$$
\mathrm{HNO}_{3}+3 \mathrm{H}^{36} \mathrm{Cl}---->{ }^{36} \mathrm{Cl}_{2}+\mathrm{NO}^{36} \mathrm{Cl}+2 \mathrm{H}_{2} \mathrm{O}
$$

There are three quantifiable sources of ${ }^{36} \mathrm{Cl}$ in the environment at the INEEL in addition to the releases made during waste processing: (1) meteoric input from wet and dry precipitation of cosmogenically produced ${ }^{36} \mathrm{Cl}$ in the Earth's atmosphere; (2) ${ }^{36} \mathrm{Cl}$ produced during nuclear-weapons tests in the 1950-60's and transported globally in the upper atmosphere; and (3) in situ production in rocks and soils by natural interactions of nuclear particles with stable elements. Meteoric input, input from nuclear-weapons-tests fallout, and in situ production of ${ }^{36} \mathrm{Cl}$ at the INEEL have only been estimated (Beasley and others, 1993). In this report, we present the first measurements and quantitative estimates of ${ }^{36} \mathrm{Cl}$ at the INEEL from meteoric and weapons-tests inputs. The in situ production estimates will be presented in a subsequent report (Cecil and others, in press).

Three measures of ${ }^{36} \mathrm{Cl}$ are used in this report: (1) concentrations expressed as atoms/L; (2) ratios of atoms of ${ }^{36} \mathrm{Cl}$ to atoms of total chloride $\left({ }^{36} \mathrm{Cl} / \mathrm{Cl}\right)$ in the samples with an associated uncertainty reported by the laboratory; and (3) atmospheric flux of ${ }^{36} \mathrm{Cl}$ in atoms per area per time 


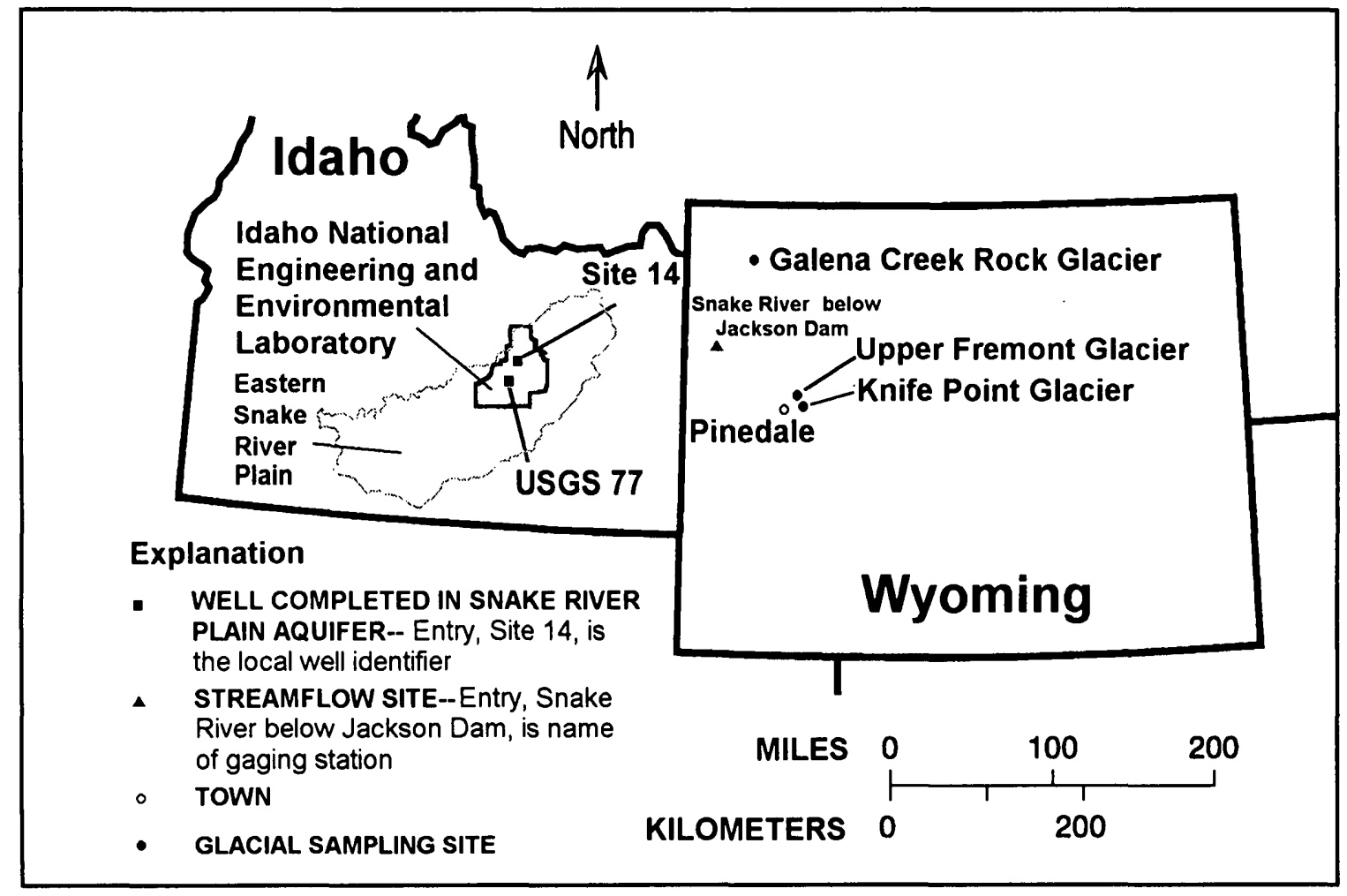

Figure 1. Location of the Idaho National Engineering and Environmental Laboratory and selected ground-water, surface-water, and glacial sampling sites. 
calculated from concentrations in the ice core (atoms/L) and precipitation flux $\left(\mathrm{g} / \mathrm{cm}^{2} \mathrm{sec}\right)$. The ratios were reported by the laboratories that made the measurements and the concentrations and fluxes were used to compare with data sets from other studies in the literature.

To aid in determining meteoric input of ${ }^{36} \mathrm{Cl}$ to the environment, 32 surface-water and 2 spring samples collected during 1969-95 from sites on and near the eastern Snake River Plain were selected for ${ }^{36} \mathrm{Cl}$ analyses (table 1). Eighteen of these samples, collected during 1969-94, were selected from the archive-sample library maintained by the U.S. Geological Survey (USGS) at the INEEL. In addition to the surface-water and spring samples, 7 ground-water and 4 snow samples were collected at and near the INEEL and analyzed for ${ }^{36} \mathrm{Cl}$. The 7 ground-water samples were collected from two USGS monitoring wells at the INEEL, Site 14 and USGS 77 (fig. 1). Two of the 4 snow samples were collected at the INEEL, (INEEL \#1, \#2; fig.2) and 2 were collected near the INEEL; the Harriman State Park sampling site is about $150 \mathrm{~km}$ northwest of the INEEL and Copper Basin is about $75 \mathrm{~km}$ west of the INEEL (fig. 2).

Chlorine- 36 produced during weapons tests in the 1950-60's has been identified in polar ice and in the ice sheet in Greenland (Finkel and others, 1980; Elmore and others, 1982). However, at mid-latitudes, Cecil and Vogt (1997) demonstrated for the first time that ice cores are suitable as archives for inventories of ${ }^{36} \mathrm{Cl}$ despite the effects of thawing and refreezing and subsequent meltwater percolation.

In 1991, a research team from the USGS collected a continuous $160-\mathrm{m}$ ice core from the Upper Fremont Glacier in the Wind River Range of Wyoming in the western United States (fig. 1). From this core, the first successful reconstruction of an isotopic record of paleoclimate from a mid-latitude North American glacier was reported (Naftz and others, 1996). Naftz and others (1996) established a global linkage of the delta oxygen-18 $\left(\delta^{18} \mathrm{O}\right)$ Standard Mean Ocean Water series between the Upper Fremont Glacier and two ice-core records from the Quelccaya Ice Cap in South America. The ice affected by the 1963 tri- tium $\left({ }^{3} \mathrm{H}\right)$ weapons peak in the Upper Fremont Glacier ice core at a depth of $29 \mathrm{~m}$ below the surface of the glacier was identified. The ${ }^{3} \mathrm{H}$ concentration at this depth was 365 tritium units. On the basis of this ${ }^{3} \mathrm{H}$ record, 18 sections of ice core ranging in length from 0.4 to $0.9 \mathrm{~m}$ were selected for ${ }^{36} \mathrm{Cl}$ analyses (table 2). These sections of ice core were selected from various depths below the surface to include ice affected by the peak weapons-tests fallout of ${ }^{36} \mathrm{Cl}$ that occurred during 1955-58 (fig. 3). The ${ }^{36} \mathrm{Cl}$ peak should be slightly deeper in the ice core than the $1963{ }^{3} \mathrm{H}$ peak. Additional sections of ice were selected to represent pre-and post-weapons-tests ${ }^{36} \mathrm{Cl}$ concentrations. A sample of relatively recent glacial runoff from Galena Creek Rock Glacier, $180 \mathrm{~km}$ north of the Upper Fremont Glacier, also was analyzed for comparison purposes (fig. 1). Glacial-runoff from the Galena Creek Rock Glacier has been shown to be of recent origin; generally from melted snow that has been deposited within the last two years (Cecil and others, 1998).

\section{Purpose and Scope}

Most ${ }^{36} \mathrm{Cl}$ produced in the hydrogeologic environment originates from cosmic radiation interacting with atmospheric gases. Additionally, large amounts of ${ }^{36} \mathrm{Cl}$, orders of magnitude larger than naturally-produced inventories, have been released to the environment during nuclear-weapons testing, nuclear-reactor operations, and nuclear-waste processing. Releases of ${ }^{36} \mathrm{Cl}$ representative of disposal practices in the nuclear industry have been documented in the hydrogeologic environment at the INEEL. To better determine the inventories of ${ }^{36} \mathrm{Cl}$ at the INEEL, a total of 64 ground- and surface-water, snow, and glacial-ice and -runoff samples were analyzed to quantify inputs from meteoric sources and fallout from nuclear-weapons tests. These samples were collected at and near the INEEL in southeastern Idaho and western Wyoming (fig. 1).

\section{Study Area}

The eastern Snake River Plain (fig. 2) is a structural downwarp filled with basalt that is generally within $3 \mathrm{~m}$ of the land surface (Whitehead, 1992). Unconsolidated sediments overlie the mar- 
Table 1. Dissolved-chloride concentration, amount of ${ }^{36} \mathrm{Cl}$-free chloride carrier added, ${ }^{36} \mathrm{Cl}$ concentration and calculated fluxes in surface-water, ground-water, spring, snow, and glacial-runoff samples (see figs. 1 and 3 for site locations; see text for explanation of uncertainties).

[SW, surface-water sample; GW, ground-water sample; SN, snow sample; SP, spring sample; GR, glacial runoff sample; USGS, U.S. Geological Survey; INEEL, Idaho National Engineering and Environmental Laboratory; ${ }^{36} \mathrm{Cl}$, chlorine-36; and ND, not determined].

\begin{tabular}{|c|c|c|c|c|c|c|}
\hline Site identifier & $\begin{array}{l}\text { Date of } \\
\text { sample }\end{array}$ & $\begin{array}{c}\text { Chloride } \\
\text { concentration } \\
(\mathrm{mg} / \mathrm{L})\end{array}$ & $\begin{array}{c}{ }^{36} \mathrm{Cl} \text {-free } \\
\text { chloride carrier } \\
(\mathrm{mg})\end{array}$ & $\begin{array}{c}\text { Measured } \\
\left.{ }^{36} \mathrm{Cl} / \mathrm{Cl}\left(\times 10^{-15}\right)\right)\end{array}$ & $\begin{array}{c}{ }^{36} \mathrm{Cl} \\
\text { concentration } \\
\left(\text { atoms } / \mathrm{L} \times 10^{8}\right)\end{array}$ & $\begin{array}{c}{ }^{36} \mathrm{Cl} \text { nux } \\
\text { (atoms/cm } \\
\times 10^{-1} \text { ) }\end{array}$ \\
\hline \multirow{5}{*}{$\begin{array}{l}\text { Little Lost } \\
\text { River-SW }\end{array}$} & $09-11-69$ & $11 \pm 0.7$ & 0 & $2,290 \pm 160$ & $1.9 \pm .0 .1$ & ND \\
\hline & $10-04-77$ & $7.4 \pm 0.6$ & 0 & $2,070 \pm 190$ & $0.3 \pm 0.01$ & ND \\
\hline & $04-08-83$ & $13 \pm 0.8$ & 0 & $3,220 \pm 250$ & $2.1 \pm 0.2$ & ND \\
\hline & $04-01-88$ & $11 \pm 0.7$ & 0 & $950 \pm 198$ & $0.7 \pm 0.1$ & ND \\
\hline & $10-11-94$ & $13 \pm 0.8$ & 0 & $998 \pm 24$ & $2.2 \pm 0.05$ & ND \\
\hline \multirow{4}{*}{$\begin{array}{l}\text { Big Lost } \\
\text { River-SW }\end{array}$} & $04-03-70$ & $4.2 \pm 0.5$ & 0 & $3,450 \pm 120$ & $1.2 \pm 0.04$ & ND \\
\hline & 1990 & $4 \pm 0.5$ & 0 & $2,461 \pm 99$ & $1.7 \pm 0.07$ & ND \\
\hline & 1991 & $3 \pm 0.4$ & 0 & $2,776 \pm 168$ & $1.4 \pm 0.08$ & ND \\
\hline & $10-11-94$ & $3.4 \pm 0.4$ & 0 & $2,369 \pm 25$ & $1.4 \pm 0.01$ & ND \\
\hline \multirow[t]{4}{*}{ Birch Creek-SW } & $04-03-70$ & $5.1 \pm 0.5$ & 0 & $960 \pm 40$ & $0.2 \pm 0.01$ & ND \\
\hline & 1990 & $5 \pm 0.5$ & 0 & $623 \pm 33$ & $0.5 \pm 0.03$ & ND \\
\hline & $03-28-91$ & $4.4 \pm 0.5$ & 0 & $672 \pm 21$ & $0.5 \pm 0.02$ & ND \\
\hline & $10-11-94$ & $4.2 \pm 0.5$ & 0 & $660 \pm 19$ & $0.5 \pm 0.01$ & ND \\
\hline \multirow[t]{3}{*}{ Camas Creek-SW } & $04-03-70$ & $5.9 \pm 0.5$ & 0 & $390 \pm 50$ & $0.2 \pm 0.02$ & ND \\
\hline & $10-03-77$ & $7.3 \pm 0.6$ & 0 & $2,170 \pm 60$ & $0.5 \pm 0.02$ & ND \\
\hline & $10-11-94$ & $7.4 \pm 0.6$ & 0 & $843 \pm 25$ & $1.1 \pm 0.03$ & ND \\
\hline Fall River-SW & $04-02-70$ & $14 \pm 0.8$ & 0 & $750 \pm 50$ & $0.4 \pm 0.03$ & ND \\
\hline $\begin{array}{l}\text { Snake River } \\
\text { below Jackson } \\
\text { Dam-SW }\end{array}$ & $04-02-70$ & $4.8 \pm 0.5$ & 0 & $2,310 \pm 70$ & $0.4 \pm 0.01$ & ND \\
\hline $\begin{array}{l}\text { Blackfoot } \\
\text { River-SW }\end{array}$ & $3-1-94$ & $13 \pm 0.8$ & 0 & $689 \pm 51$ & $1.5 \pm 0.1$ & ND \\
\hline $\begin{array}{l}\text { Snake River at } \\
\text { Shelley-SW }\end{array}$ & $3-1-94$ & $12 \pm 0.8$ & 0 & $567 \pm 33$ & $1.2 \pm 0.1$ & ND \\
\hline $\begin{array}{l}\text { Snake River at } \\
\text { Irwin-SW }\end{array}$ & $3-2-94$ & $6.8 \pm 0.6$ & 0 & $894 \pm 42$ & $1.0 \pm 0.05$ & ND \\
\hline $\begin{array}{l}\text { Snake River at } \\
\text { Heise Bridge-SW }\end{array}$ & $3-2-94$ & $19 \pm 1$ & 0 & $311 \pm 21$ & $1.0 \pm 0.1$ & ND \\
\hline Teton River-SW & $3-2-94$ & $3.3 \pm 0.4$ & 0 & $2,630 \pm 210$ & $1.5 \pm 0.1$ & ND \\
\hline
\end{tabular}


Table 1. Dissolved-chloride concentration, amount of ${ }^{36} \mathrm{Cl}$-free chloride carrier added, ${ }^{36} \mathrm{Cl}$ concentration and calculated fluxes in surface-water, ground-water, spring, snow, and glacial runoff samples (see figs. 1 and 3 for site locations; see text for explanation of uncertainties).--continued

\begin{tabular}{|c|c|c|c|c|c|c|}
\hline Site identifier & $\begin{array}{l}\text { Date of } \\
\text { sample }\end{array}$ & $\begin{array}{c}\text { Chloride } \\
\text { concentration } \\
(\mathrm{mg} / \mathrm{L})\end{array}$ & $\begin{array}{c}{ }^{36} \mathrm{Cl}-\text { free } \\
\text { chloride carrier } \\
(\mathrm{mg})\end{array}$ & $\begin{array}{l}\text { Measured } \\
{ }^{36} \mathrm{Cl} / \mathrm{Cl}\left(\times 10^{-15}\right)\end{array}$ & $\begin{array}{c}{ }^{36} \mathrm{Cl} \\
\text { concentration } \\
\left(\text { atoms } / \mathrm{L} \times 10^{8}\right)\end{array}$ & $\begin{array}{c}{ }^{36} \mathrm{Cl} \text { flux } \\
\text { (atoms } / \mathrm{cm}^{2} \mathrm{sec} \\
\left.\times 10^{-1}\right)\end{array}$ \\
\hline $\begin{array}{l}\text { Henrys Fork at St. } \\
\text { Anthony-SW }\end{array}$ & $3-3-94$ & $2.3 \pm 0.4$ & 0 & $3,040 \pm 190$ & $1.2 \pm .0 .1$ & ND \\
\hline $\begin{array}{l}\text { Medicine Lodge } \\
\text { Creek-SW }\end{array}$ & $3-3-94$ & $6.3 \pm 0.5$ & 0 & $2,230 \pm 120$ & $2.4 \pm 0.1$ & ND \\
\hline Beaver Creek-SW & $3-3-94$ & $4.4 \pm 0.5$ & 0 & $8,300 \pm 970$ & $6.2 \pm 0.7$ & ND \\
\hline $\begin{array}{l}\text { Portneuf } \\
\text { River-SW }\end{array}$ & $3-4-94$ & $37 \pm 2$ & 0 & $417 \pm 41$ & $2.6 \pm 0.3$ & ND \\
\hline $\begin{array}{l}\text { Snake river Near } \\
\text { Neely-SW }\end{array}$ & $3-4-94$ & $36 \pm 2$ & 0 & $277 \pm 18$ & $1.7 \pm 0.1$ & ND \\
\hline $\begin{array}{c}\text { Snake River at } \\
\text { Milner-SW }\end{array}$ & $3-4-94$ & $29 \pm 1$ & 0 & $387 \pm 15$ & $1.9 \pm 0.1$ & ND \\
\hline $\begin{array}{l}\text { Snake River at } \\
\text { King Hill-SW }\end{array}$ & $3-5-94$ & $25 \pm 1$ & 0 & $442 \pm 33$ & $1.9 \pm 0.1$ & ND \\
\hline $\begin{array}{l}\text { Big Wood } \\
\text { River-SW }\end{array}$ & $3-5-94$ & $5.3 \pm 0.5$ & 0 & $3,850 \pm 200$ & $3.5 \pm 0.2$ & ND \\
\hline Silver Creek-SW & $3-5-94$ & $4.4 \pm 0.5$ & 0 & $4,180 \pm 200$ & $3.1 \pm 0.2$ & ND \\
\hline $\begin{array}{l}\text { Liddy Hot } \\
\text { Spring-SP }\end{array}$ & $3-14-94$ & $7.2 \pm 0.6$ & 0 & $235 \pm 8$ & $0.28 \pm 0.01$ & ND \\
\hline Big Spring-SP & $6-27-95$ & $2.6 \pm 0.4$ & 0 & $33.6 \pm 2.5$ & $0.014 \pm 0.001$ & ND \\
\hline \multirow[t]{2}{*}{ Site 14-GW } & $9-7-77$ & $9.2 \pm 0.7$ & 2.01 & $141 \pm 7$ & $0.06 \pm 0.003$ & ND \\
\hline & $10-15-93$ & $8.2 \pm 0.6$ & 1.07 & $212 \pm 6$ & $0.04 \pm 0.001$ & ND \\
\hline \multirow[t]{5}{*}{ USGS 77-GW } & $5-10-68$ & $65 \pm 3$ & 11.97 & $7,840 \pm 110$ & $16,000 \pm 225$ & ND \\
\hline & $4-25-69$ & $73 \pm 3$ & 117.6 & $10,400 \pm 500$ & $19,000 \pm 914$ & ND \\
\hline & $4-21-71$ & $71 \pm 3$ & 112.1 & $8,880 \pm 290$ & $17,000 \pm 556$ & ND \\
\hline & $9-6-77$ & $79 \pm 3$ & 12.31 & $8,110 \pm 220$ & $17,100 \pm 463$ & ND \\
\hline & $11-1-93$ & $120 \pm 5$ & 11.8 & $6,180 \pm 90$ & $12,500 \pm 182$ & ND \\
\hline $\begin{array}{l}\text { Harriman State } \\
\text { Park-SN }\end{array}$ & $12-10-91$ & $0.9 \pm 0.2$ & 16 & $74 \pm 10$ & $0.063 \pm 0.009$ & $0.12 \pm 0.02$ \\
\hline Copper Basin-SN & $3-15-91$ & $0.5 \pm 0.1$ & 24 & $50 \pm 25$ & $0.049 \pm 0.025$ & $0.03 \pm 0.02$ \\
\hline INEEL \# 1-SN & $1-24-91$ & $0.25 \pm 0.05$ & 24 & $17,939 \pm 469$ & $14 \pm 0.4$ & $10 \pm 0.3$ \\
\hline INEEL \#2-SN & $1-24-91$ & $0.95 \pm 0.19$ & 24 & $177,900 \pm 35,580$ & $170 \pm 34$ & $120 \pm 24$ \\
\hline $\begin{array}{c}\text { Galena Creek } \\
\text { Rock Glacier-GR }\end{array}$ & $8-30-95$ & $0.079 \pm 0.004$ & 0.722 & $170 \pm 25$ & $0.032 \pm 0.005$ & $0.16 \pm 0.02$ \\
\hline
\end{tabular}




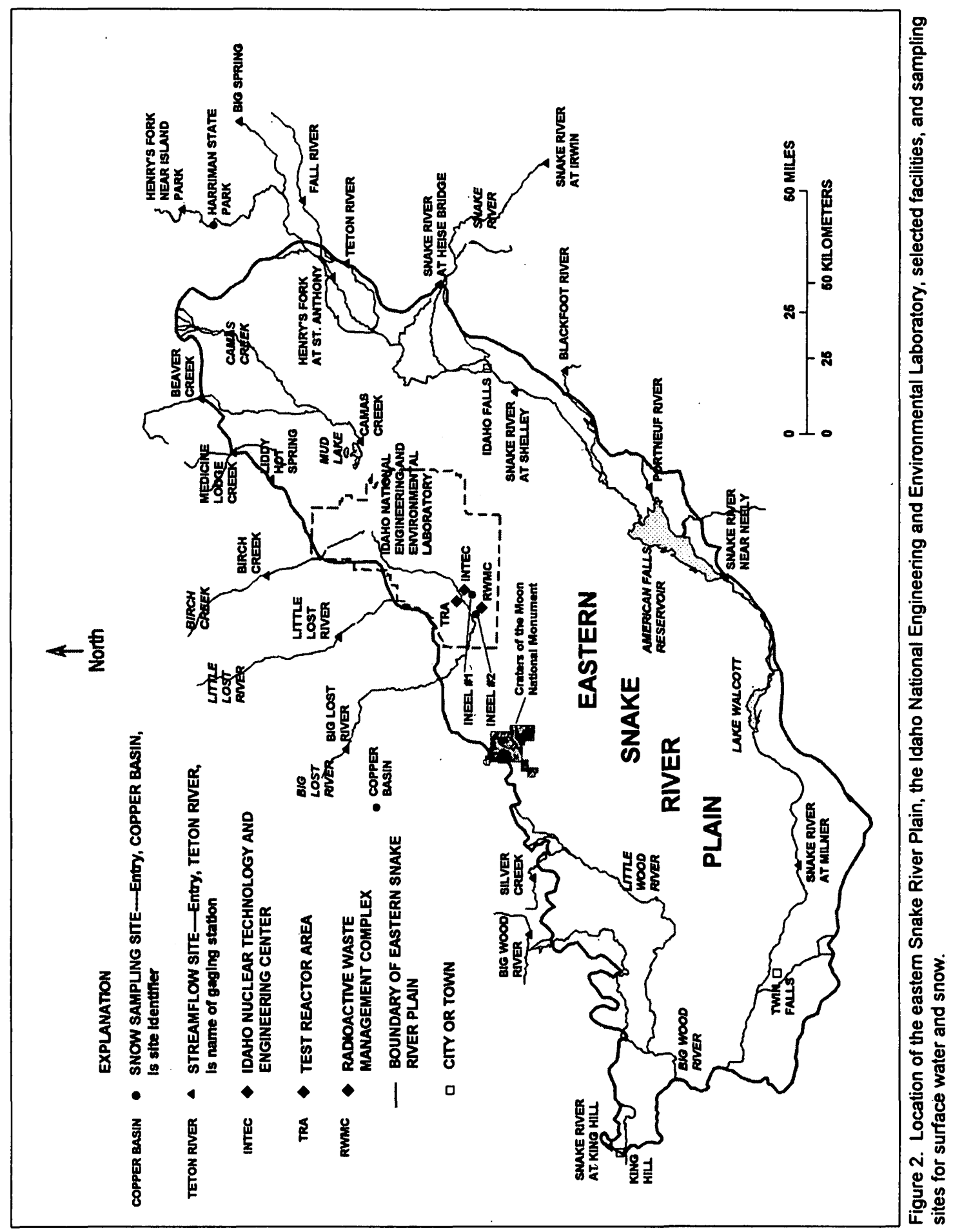


Table 2. Dissolved-chloride concentration, amount of ${ }^{36} \mathrm{Cl}$-free chloride carrier added, ${ }^{36} \mathrm{Cl}$ concentration, and calculated fluxes in samples from ice core collected in the summer of 1991 from the Upper Fremont Glacier, Wyoming (see fig. 1 for the location of the Upper Fremont Glacier; see text for explanation of uncertainties).

$\left[{ }^{36} \mathrm{Cl}\right.$, chlorine-36; m, meters; mg, milligram; atom/g, atoms per gram; and atoms $/ \mathrm{cm}^{2} \mathrm{sec}$, atoms per square centimeter per second]

\begin{tabular}{|c|c|c|c|c|c|c|}
\hline $\begin{array}{l}\text { Depth below } \\
\text { glacial surface } \\
\text { (m) }\end{array}$ & $\begin{array}{l}\text { Core } \\
\text { length } \\
(\mathrm{m})\end{array}$ & $\begin{array}{c}\text { Dissolved } \\
\text { chloride }(\mathrm{mg} / \mathrm{L}) \\
\pm 20 \text { percent }\end{array}$ & $\begin{array}{c}{ }^{36} \mathrm{Cl} \text {-free } \\
\text { chloride carrier } \\
(\mathrm{mg})\end{array}$ & $\begin{array}{l}\text { In Situ } \\
{ }^{36} \mathrm{Cl} / \mathrm{Cl}\left(\times 10^{-15}\right)\end{array}$ & $\begin{array}{c}{ }^{36} \mathrm{Cl} \\
\text { concentration } \\
\left(\text { atoms } / \mathrm{g} \times 10^{4}\right)\end{array}$ & $\begin{array}{c}{ }^{36} \mathrm{Cl} \text { flux } \\
\text { (atoms } / \mathrm{cm}^{2} \mathrm{sec} \\
\times 10^{-1} \text { ) }\end{array}$ \\
\hline $19.6-20.5$ & 0.9 & 0.19 & 1.03 & $860 \pm 80$ & $0.28 \pm 0.03$ & $0.11 \pm 0.02$ \\
\hline $24.0-24.5$ & .5 & .25 & .85 & $3,900 \pm 100$ & $1.7 \pm 0.05$ & $.63 \pm 0.03$ \\
\hline $24.5-25.0$ & .5 & .11 & .99 & $7,600 \pm 200$ & $1.4 \pm 0.04$ & $.54 \pm 0.02$ \\
\hline $29.8-30.4$ & .6 & .08 & 1.71 & $24,000 \pm 1,000$ & $3.2 \pm 0.1$ & $1.2 \pm 0.1$ \\
\hline $30.4-31.1$ & .7 & .09 & 1.69 & $28,000 \pm 1,000$ & $4.3 \pm 0.1$ & $1.6 \pm 0.1$ \\
\hline $31.1-31.5$ & .4 & .20 & 1.44 & $19,000 \pm 1,000$ & $6.5 \pm 0.2$ & $2.5 \pm 0.1$ \\
\hline $31.5-32.0$ & .5 & .16 & 1.69 & $28,000 \pm 1,000$ & $7.7 \pm 0.2$ & $2.9 \pm 0.1$ \\
\hline $32.0-32.5$ & .5 & .14 & 1.08 & $23,000 \pm 3,000$ & $5.5 \pm 0.7$ & $2.1 \pm 0.3$ \\
\hline $32.5-33.1$ & .6 & .13 & 1.00 & $16,000 \pm 2,000$ & $3.4 \pm 0.5$ & $1.3 \pm 0.2$ \\
\hline $33.1-33.6$ & .5 & .38 & 0.95 & $9,600 \pm 1,000$ & $6.2 \pm 0.6$ & $2.4 \pm 0.2$ \\
\hline $33.6-34.2$ & .6 & .12 & 1.02 & $16,000 \pm 2,000$ & $3.2 \pm 0.4$ & $1.2 \pm 0.1$ \\
\hline $34.2-34.8$ & .6 & .14 & 1.02 & $9,900 \pm 200$ & $2.4 \pm 0.1$ & $.90 \pm 0.02$ \\
\hline $34.8-35.3$ & .5 & .38 & 1.02 & $4,300 \pm 100$ & $2.8 \pm 0.1$ & $1.1 \pm 0.02$ \\
\hline $39.6-40.2$ & .6 & .18 & .80 & $4,500 \pm 200$ & $1.4 \pm 0.05$ & $.53 \pm 0.01$ \\
\hline $40.2-40.6$ & .4 & .09 & .81 & $8,900 \pm 300$ & $1.4 \pm 0.05$ & $.52 \pm 0.01$ \\
\hline $45.2-46.4$ & .8 & .35 & 1.03 & $3,200 \pm 400$ & $1.0 \pm 0.01$ & $.39 \pm 0.05$ \\
\hline $104.7-105.5$ & .8 & .19 & 1.81 & $370 \pm 60$ & $.12 \pm 0.02$ & $.045 \pm 0.007$ \\
\hline $105.5-106.3$ & .8 & .07 & 1.87 & $4,400 \pm 300$ & $.52 \pm 0.04$ & $.20 \pm 0.02$ \\
\hline
\end{tabular}



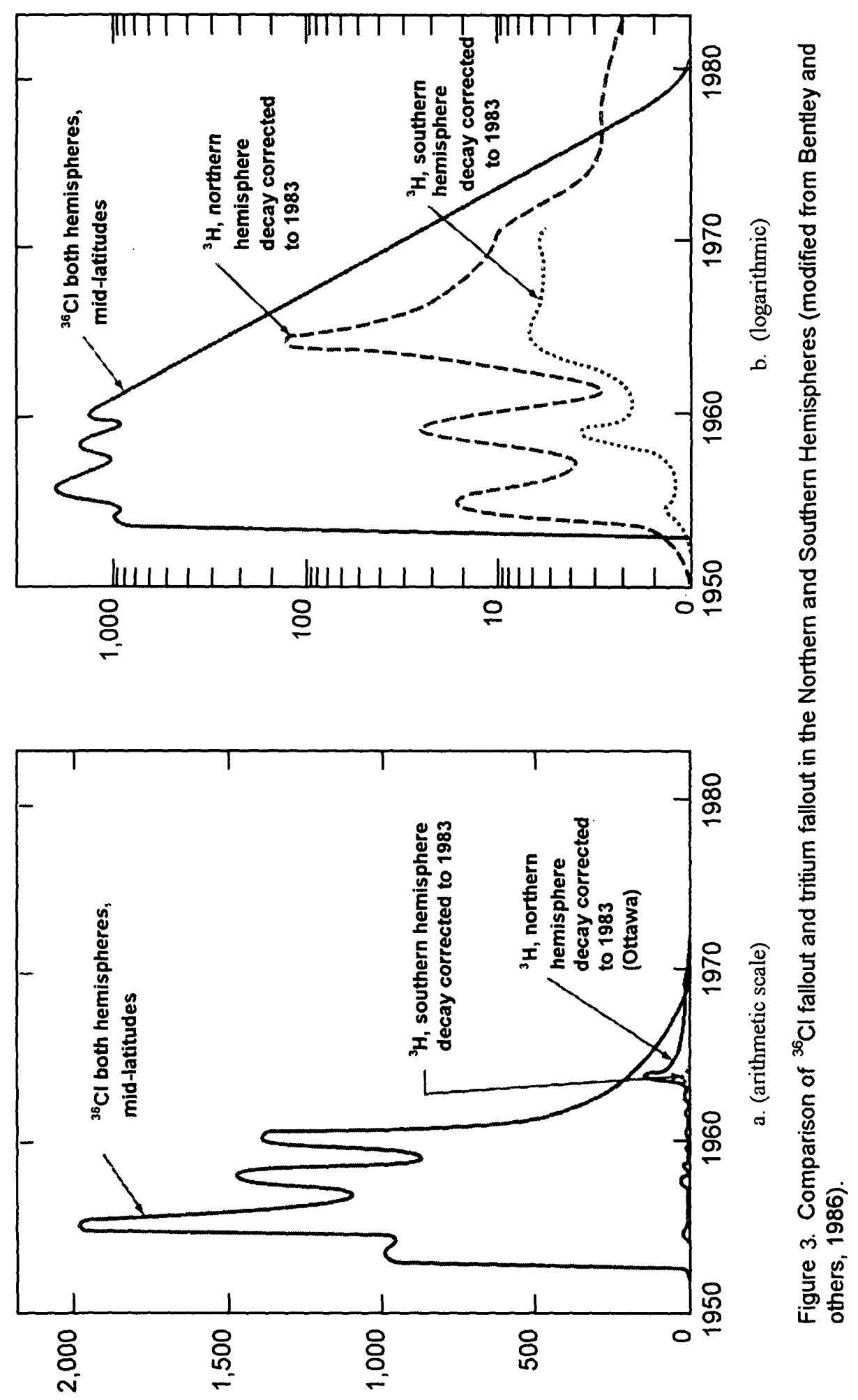
gins of the plain and are interbedded with the basalts and cinder beds at depth. The basalts are several hundred to as much as $1,500 \mathrm{~m}$ thick and underlie most of the plain. Fractures and vesicular zones occur near the surfaces of the basalt flows and may be highly transmissive of ground water. Reported transmissivities for the eastern Snake River Plain aquifer range from 0.1 to more than $70,000 \mathrm{~m}^{2} /$ day, a range of nearly six orders of magnitude (Ackerman, 1991). Depth to ground water at the INEEL varies in the basalt aquifer from about $60 \mathrm{~m}$ below land surface in the northern part to more than $275 \mathrm{~m}$ in the southern part. The hydraulic gradient at the INEEL is about $1 \mathrm{~m} / \mathrm{km}$ and horizontal ground-water flow velocities range from 1 to $7 \mathrm{~m} /$ day. This range is based on the distribution of ${ }^{36} \mathrm{Cl}$ through time as determined from analyses of archived samples (Cecil, unpublished data, 1998).

Long-term (1950-88) average precipitation in the vicinity of the INEEL is $22 \mathrm{~cm} /$ year (Clawson and others, 1989, table D-1). About 40 percent of the long-term average precipitation on the eastern Snake River Plain is rainfall between April and September. However, as a result of evapotranspiration, less than 5 percent of that precipitation infiltrates the surface locally on the Snake River Plain (Cecil and others, 1992). Recharge to the eastern Snake River Plain aquifer is from snowmelt in the mountains to the east, west and north, and from irrigation return flow and surface water. The five watersheds that recharge the aquifer are the Big Lost River, Little Lost River, Birch Creek, Camas Creek/Mud Lake, and the main Snake River drainage (fig. 2).

The INEEL comprises about $2,300 \mathrm{~km}^{2}$ of the eastern Snake River Plain in southeastern Idaho. The INEEL was established in 1949 and is used by the U.S. Department of Energy (DOE) to construct and test nuclear reactors and to participate in various defense programs. Radiochemical and chemical wastes generated at the INEEL and other DOE facilities have been buried at the site since 1952. Additionally, from 1952-84, low-level radioactive and chemical wastes were disposed into the Snake River Plain aquifer at the Idaho Nuclear Technology and Engineering Center (INTEC) through a 182 -m-deep disposal well. Since 1984 at the INTEC, and from 1952-93 at the Test Reactor Area (fig. 2), these wastes also have been discharged to infiltration ponds. The wastewater discharged to ponds at these two facilities must travel through about $150 \mathrm{~m}$ of alluvium, sedimentary interbeds, and basalt before reaching the aquifer.

\section{Previous Investigations}

Pre-weapons tests ${ }^{36} \mathrm{Cl} / \mathrm{Cl}$ ratios were estimated for the continental United States (Bentley and others, 1986). These researchers used calculations done by Lal and Peters (1967) for meteoric ${ }^{36} \mathrm{Cl}$ fallout with latitude divided by total chloride in precipitation from Eriksson (1960). Similar pre-weapons-tests ratios as those estimated by Bentley and others for the latitude of the INEEL ( 320 to $640 \times 10^{-15}$, fig. 4 ) have been reported by Cecil and others (1992) for soil water extracted from the shallow alluvium at the Radioactive Waste Management Complex (RWMC) (fig. 2). It was determined that soil water representative of pre-weapons-tests ${ }^{36} \mathrm{Cl} / \mathrm{Cl}$ ratios from depths ranging from 2.4 to $5.6 \mathrm{~m}$ below land surface had values near $320 \times 10^{-15} ;{ }^{36} \mathrm{Cl} / \mathrm{Cl}$ ratios ranged from $260 \pm 12 \times 10^{-15}$ to $290 \pm 14 \times 10^{-15}$.

Chlorine- 36 concentrations and estimated fluxes were reported for the eastern United States (Hainsworth and others, 1994) and for the central United States (Knies and others, 1994). Pre- and post-weapons-tests concentrations and fluxes reported in those studies are nearly the same as concentrations and fluxes reported here. The first identification of weapons-tests-produced ${ }^{36} \mathrm{Cl}$ in glacial ice of North America was reported by Cecil and Vogt (1997). This report is a continuation of that work.

\section{Acknowledgements}

Thanks are given to Dave Naftz, USGS, for providing the glacial-ice samples used in this study and to Joan Fitzpatrick and Geoffrey Hargreaves, USGS, for their help in processing the ice core at the National Ice Core Laboratory in Denver, Colorado. Thanks are also given to Tom Beasley, DOE Environmental Measurements Laboratory in New York for preparing the silver chloride targets used in the Accelerator Mass Spectrometric measurements on the process blanks, PB-1 through PB-4, 


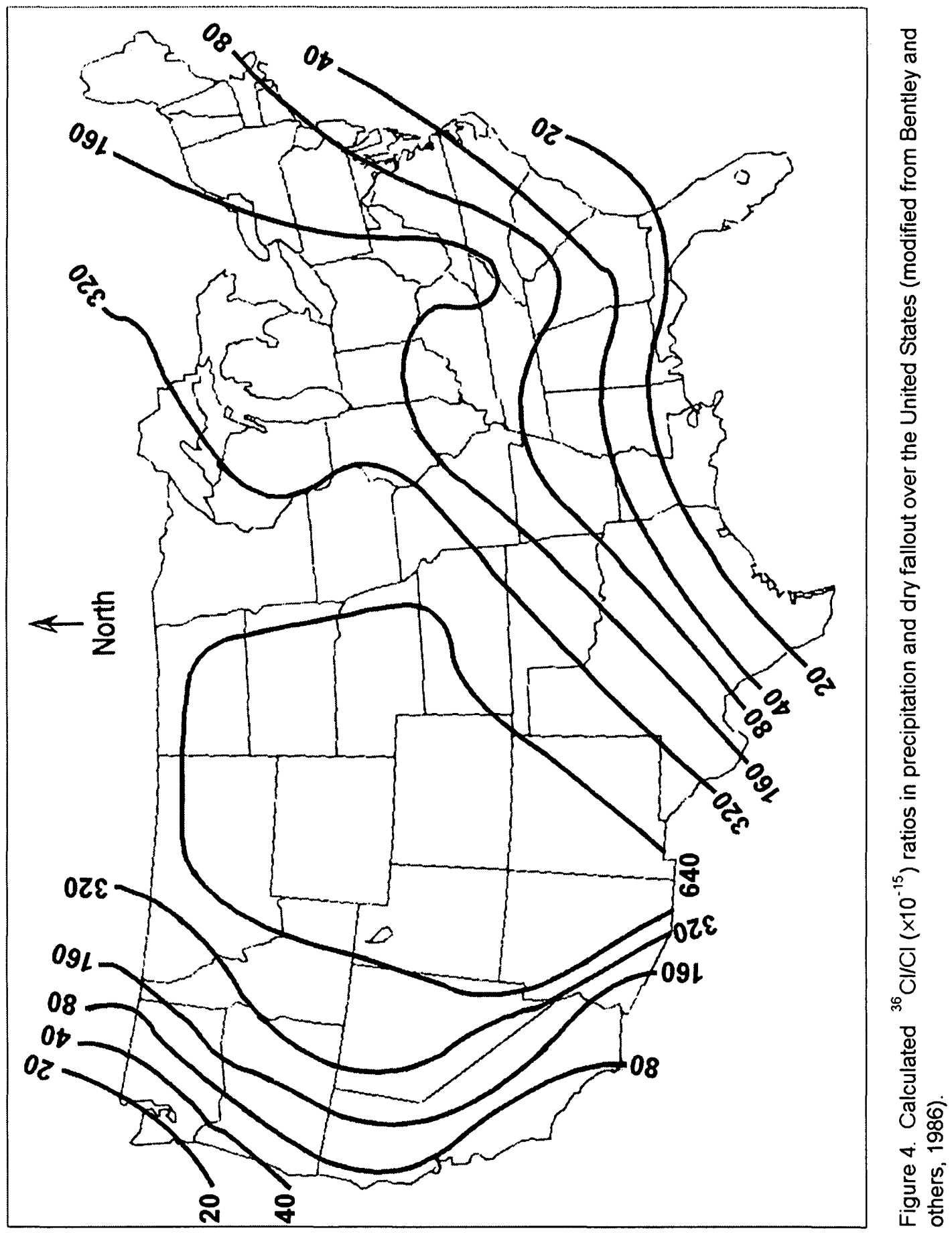


and on the 4 snow samples. Additional thanks are given to Linford Campbell, Idaho Department of Water Resources, and Travis McLing, Lockheed Martin Idaho Technologies Company, for their constructive review of the report.

\section{METHODS AND QUALITY ASSURANCE}

The ground-water, surface-water, and spring samples were analyzed for dissolved chloride by the ion-chromatography method (Fishman and Friedman, 1989). Internal standards were analyzed to ensure that all data were within acceptance limits. A standard two-column ion chromatography technique was employed. Water samples were placed in a liquid mobile phase (eluent) and pumped at a constant flow rate through two ion-exchange columns in tandem. In the first column, chloride ions were separated from the solution on the basis of their affinity for exchange sites on an anion-specific resin. The second column decreased the background conductivity of the eluent to a minimal level to suppress interference. Separated chloride ions then were quantified with a specific-conductance cell, and an anion chromatograph was produced.

Because the results of chloride analyses performed by the USGS's National Water Quality Laboratory (NWQL) for ground-water, surface-water, and spring samples were not reported with a sample standard deviation, sample standard deviations were calculated using the following method. The USGS Quality Assurance (QA) unit conducts a blind-sample program in which reference samples disguised as environmental samples are submitted to the laboratory for analyses (Maloney and others, 1993). These blind-sample program data are stored in the USGS data base (QADATA) and are accessible through the USGS computer system (Lucey, 1990). The statistical analyses generated through the QADATA program include equations generated by using linear-least-squares regression of a most probable value for a given analyte from the USGS's Standard Reference Water Sample program during the previous seven years compared to a corresponding concentration generated in the laboratory for an environmental sample. These linear-regression equations facilitate the calculation of a most prob- able deviation (MPD) at most concentrations for most analytes in samples submitted to the NWQL for analyses. The following equation from Maloney and others (1993) was used to estimate the sample standard deviations (or MPD) in table 1 for chloride concentrations reported by the NWQL:

$$
y=0.039 x+0.30
$$

where:

$y$ is the calculated sample standard deviation, in $\mathrm{mg} / \mathrm{L}$, and

$x$ is the reported chloride concentration, in $\mathrm{mg} / \mathrm{L}$.

The ice samples used in this study were stored and processed for analyses at the National Ice Core Laboratory in Denver, Colorado. The ice cores were cut using a band saw operated in a walk-in freezer where the air temperature is maintained at less than $-10^{\circ} \mathrm{C}$. Sections of the ice core selected for ${ }^{36} \mathrm{Cl}$ analyses were scraped with a stainless steel microtome and then rinsed with ultrapure (18 megohm-cm) deionized water. The ice cores then were slowly melted in a microwave oven. A laboratory blank of the 18 megaohm deionized water and two process blanks prepared by the staff at PRIME Laboratory at Purdue University were analyzed with the melted ice cores. The deionized water blank and the process blank PRIME B-1 did not contain ${ }^{36} \mathrm{Cl}$ (table 3). Process Blank PRIME B-2 contained ${ }^{36} \mathrm{Cl}$ at a small concentration that was used to blank correct all samples that were measured at the same time as PRIME B-2. Chlorine was separated from the melted ice by precipitation as silver chloride $(\mathrm{AgCl})$ and analyses for ${ }^{36} \mathrm{Cl}$ were performed.

The concentrations of dissolved chloride in the snow, glacial-ice and -runoff samples were determined using a low-level ion chromatography (IC) system consisting of a Dionex AI-4500 Ion Chromatograph, AS4A $(4 \times 250 \mathrm{~mm})$ and AG4A $(4 \times 50 \mathrm{~mm})$ columns, and a computer interface that downloaded the data directly to a computer file (Fishman and Friedman, 1989). A 1.8 milliMolar (mM) sodium carbonate and $1.70 \mathrm{mM}$ sodium bicarbonate eluent with a constant flow 
Table 3. Dissolved-chloride concentration, amount of ${ }^{36} \mathrm{Cl}$-free chloride carrier added,and measured ${ }^{36} \mathrm{Cl} / \mathrm{Cl}$ in quality-assurance samples

[mg/L, milligrams per liter; ${ }^{36} \mathrm{Cl}$, chlorine-36; and $\mathrm{mg}$, milligrams]

\begin{tabular}{ccccc}
\hline Site or sample identifier & $\begin{array}{c}\text { Date of } \\
\text { sample }\end{array}$ & $\begin{array}{c}\text { Chloride concentration } \\
(\mathbf{m g} / \mathbf{L})\end{array}$ & $\begin{array}{c}{ }^{36} \mathrm{Cl} \text {-free } \\
\text { chloride carrier } \\
(\mathbf{m g})\end{array}$ & Measured ${ }^{36} \mathrm{Cl} / \mathrm{Cl}^{\left(\times 10^{-15}\right)}$ \\
\hline Deionized Water & 1995 & $<0.01$ & $<1.71$ & $< \pm 16$ \\
PRIME B-1 & 1995 & $<0.01$ & $<3.83$ & $1 \pm 1$ \\
PRIME B-2 & 1993 & $<0.01$ & 24 & $0 \pm 10$ \\
PB-1 & 1991 & $<0.01$ & 24 & $0 \pm 10$ \\
PB-2 & 1991 & $<0.01$ & 24 & $15 \pm 10$ \\
PB-3 & 1991 & $<0.01$ & 24 & $24 \pm 16$ \\
PB-4 & 1991 & $<0.01$ & & 24 \\
\hline
\end{tabular}

rate of $1.0 \mathrm{~mL}$ per minute was used. The concentration of the anions was then determined using a micromembrane suppressor and a conductivity detector.

Eight hundred microliters of the sample were loaded onto the column. The anions were extracted onto the stationary-phase resin of the column. The anions were eluted off of the column at specific times and in a specific order using the carbonate/bicarbonate eluent. The sample stream passed through a suppressor which lowered the baseline conductivity, thereby lowering the method detection limit. The stream was then routed past a conductivity detector that showed increased conductivity as peaks on a chart recorder when the number of ions in the stream increased. The timing of these peaks indicated which anion was present and the magnitude of the peak revealed the amount in the sample.

Fifty percent of each group of samples submitted for analyses were quality control (QC) samples. These consisted of Standard Reference Water Samples, blanks, calibration standards and blind QC samples. Two separate blind-sample programs submit samples to the NWQL, one program is administered by the Quality Assurance Unit and the other by the Branch of Technical Development and Quality Systems. Charts of the blind QC output are available from each of these programs. These charts indicate that the IC line used for the snow and glacial-ice and -runoff samples was operating with no shifts in trends, no significant bias, and all data were within the acceptance limits. The QA/QC data and charts are available for inspection at the USGS Project Office at the INEEL.

The chloride analyses performed on the snow and glacial-ice and -runoff samples by the NWQL had a standard deviation of $0.014 \mathrm{mg} / \mathrm{L}$ at concentrations of $0.07 \mathrm{mg} / \mathrm{L}$. This standard deviation was calculated from on-line QC data collected from 25 separate analyses of Standard Reference Water Sample P-13 and represents an associated uncertainty of 20 percent. The 25 values used were collected from January 1996 to May 1996 and are similar to data collected from previous years. Standard Reference Water Sample P-13 was made by the Branch of Technical Development and Quality Systems and is regularly used as a QC sample on the analytical instrument used for this study. The results for this Standard Reference Water Sample are similar to results obtained by both blind-sample programs at the NWQL. Therefore, all dissolved chloride concentrations determined for the snow and glacial-ice and -runoff samples were assigned an associated uncertainty of 20 percent (table 2 ).

Until $1977,{ }^{36} \mathrm{Cl}$ in environmental samples was measured by counting beta-particle emissions during radioactive decay. These kinds of measurements were difficult because of the relatively long half-life and the corresponding small specific radioactivity of ${ }^{36} \mathrm{Cl}$. However, Muller (1977) postulated that by using particle accelerators as mass 
spectrometers, radionuclides with relatively long half-lives, such as carbon- $14\left({ }^{14} \mathrm{C}\right)$ and beryllium-10, could be measured at environmental concentrations. Later in 1977, accelerator mass spectrometer (AMS) measurements of ${ }^{14} \mathrm{C}$ were reported by McMaster University in Canada and the University of Rochester in the United States. In 1979 , the first successful measurements of ${ }^{36} \mathrm{Cl}$ in ground-water samples were carried out at the University of Rochester on a tandem Van De Graaff accelerator system; the first such use of accelerators had been for helium-3 measurements in 1939 by Alvarez and Cornog (Elmore and others, 1979). Since 1979, thousands of environmental samples have been measured for ${ }^{36} \mathrm{Cl}$ concentrations at several accelerator facilities throughout the world.

Conventional beta-decay counting methods required tens of grams of chloride, and counting times as long as a week were common. The AMS method requires as little as $1.0 \mathrm{mg} / \mathrm{L}$ total chloride with corresponding counting times of thirty minutes and 10 percent precision. Sensitivity also has improved. Sensitivity of beta-counting methods is about one ${ }^{36} \mathrm{Cl}$ atom in $10^{12}$ chlorine atoms and sensitivity of AMS methods is about 5 atoms of ${ }^{36} \mathrm{Cl}$ in $10^{15}$ chlorine atoms. This AMS sensitivity corresponds to about one beta-particle emission per year; this measurement is not feasible by conventional beta-decay counting.

AMS operates on the same principle as conventional mass spectrometry, that all charged atomic and molecular species have unique masses. Just as in mass spectrometry, AMS consists of four steps: (1) formation of negatively charged atomic or molecular species; (2) acceleration of these species through an electrostatic potential; (3) separation of ions based on their mass-to-charge ratios; and (4) particle identification in a detector system. In the AMS method, acceleration is through electrostatic potential of megaelectron volt energies in contrast to kiloelectron volt energies found in conventional mass spectrometry. Molecular interference is eliminated as particles are accelerated to larger energies. In the case of ${ }^{36} \mathrm{Cl}$, isobaric interference is from sulfur- $36\left({ }^{36} \mathrm{~S}\right)$. Therefore, most of the sulfate in the sample used in this study was removed in the chemical preparation of targets for AMS. The remaining
${ }^{36} \mathrm{~S}$ was suppressed by the range-energy separation method.

Ground- and surface-water samples, the glacial-ice and -runoff samples, and the deionized water and blanks PRIME B-1 and B-2 (table 3) were analyzed for ${ }^{36} \mathrm{Cl}$ at PRIME Laboratory, Purdue University. The PRIME Laboratory AMS facility contains an upgraded 8-million volt tandem accelerator with a high intensity ion source, a 75-thousand volt ion-source injector, and a beamline and detector system. Positive ions of cesium are used to sputter chloride ions from a Silver Chloride $(\mathrm{AgCl})$ target. The negative ions are focused and passed through a $90^{\circ}$-angle inflection magnet and accelerated toward a fixed positive terminal potential midway through the tandem accelerator. The negative ions pass through a carbon foil that strips off valence electrons and breaks the molecular species. The resultant beam of positive ions is accelerated toward ground potential. After passing through a $90^{\circ}$-angle magnet and an electrostic analyzer, the ${ }^{36} \mathrm{Cl}$ ions are distinguished from ${ }^{36} \mathrm{~S}$ and identified in a gas-ionization detector.

The process blank water samples designated PB-1 through PB-4 in table 3 and the 4 snow samples were analyzed for ${ }^{36} \mathrm{Cl}$ at the AMS facility at the University of Rochester's Nuclear Structure Research Laboratory, New York. The AMS facility at the University of Rochester was of similar configuration as the facility at Purdue University. As part of the QA/QC for this project, several water samples were measured for ${ }^{36} \mathrm{Cl} / \mathrm{Cl}$ ratios at both PRIME Laboratory and the Nuclear Structure Research Laboratory. There was statistical agreement between the results from the two laboratories on blind duplicate samples and on duplicates of the same sample analyzed several months apart (Beasley and others, 1993, table 1).

For AMS target preparation, samples were acidified to $\mathrm{pH} 2$ using ultrapure nitric acid. Chloride concentrations in the melted snow and glacial-ice and -runoff samples were small $(0.07$ to $0.95 \mathrm{mg} / \mathrm{L}$ ); therefore, 0.8 to $24 \mathrm{mg}$ (as chloride) of ${ }^{36} \mathrm{Cl}$-free chloride carrier were added to each sample for the AMS target preparation (tables 1 and 2). Chloride then was precipitated from the acidified samples as $\mathrm{AgCl}$ by the addition of 15 
$\mathrm{mL}$ of 0.1 molar $(\mathrm{M})$ ultrapure silver nitrate. The precipitate was filtered using a Millipore $250-\mathrm{mL}$ filtering system with $0.45-\mu \mathrm{m}$ cellulose nitrate filters. After filtration, the $\mathrm{AgCl}$ precipitate was washed several times with dilute ultrapure nitric acid. A few drops of ultrapure silver nitrate were added to an aliquot of the filtrate to test for any unprecipitated chloride. The $\mathrm{AgCl}$ was dissolved by the addition of 10 to $20 \mathrm{~mL}$ of $4 \mathrm{M}$ ultrapure sodium hydroxide to the filter cup. Several rinses with sodium hydroxide ensured that all of the chloride was transferred to the test tube.

To remove sulfate ions $\left(\mathrm{SO}_{4}{ }^{-}\right)$from the $\mathrm{AgCl}$ precipitate, an ultrapure barium nitrate $\left(\mathrm{Ba}\left(\mathrm{NO}_{3}\right)_{2}\right)$ solution was prepared by adding $100 \mathrm{~mL}$ of $1 \mathrm{M}$ ultrapure nitric acid to an excess of ultrapure barium carbonate (approximately $25 \mathrm{~g}$ ). A few drops of the $\mathrm{Ba}\left(\mathrm{NO}_{3}\right)_{2}$ solution then were added to remove $\mathrm{SO}_{4}{ }^{3}$ according to the following reaction:

$$
\begin{aligned}
& \mathrm{Ba}\left(\mathrm{NO}_{3}\right)_{2} \text { (aqueous) }+\mathrm{SO}_{4}{ }^{=} \text {(aqueous) } \rightarrow \\
& \mathrm{BaSO}_{4} \text { (solid) }+2 \mathrm{NO}_{3}{ }^{-} \text {(aqueous) }
\end{aligned}
$$

The sample was allowed to stand overnight to ensure complete precipitation of the barium sulfate $\left(\mathrm{BaSO}_{4}\right)$. The sample was gravity filtered, the precipitate was washed and discarded, and the sample was acidified to $\mathrm{pH} 1$ by the addition of concentrated ultrapure nitric acid. This resulted in the reprecipitation of $\mathrm{AgCl}$ that was isolated by centrifugation. After three washing and recentrifugation steps, the final product was dried overnight in an oven at $90^{\circ} \mathrm{C}$. The prepared samples were stored in amber glass vials to prevent photodecomposition of the $\mathrm{AgCl}$.

\section{METEORIC INPUT}

The most direct method to determine meteoric input of ${ }^{36} \mathrm{Cl}$ is the long-term monitoring of concentrations in wet and dry precipitation. However, several problems must be dealt with before the assumption can be made that these concentrations are representative of initial meteoric water. For arid regions such as the INEEL, precipitation events are infrequent and an accurate assessment of meteoric concentrations may take several years of measurements. Additionally, seasonal trends in
${ }^{36} \mathrm{Cl}$ deposition do exist (Hainsworth and others, 1994) and maximum recharge to the local ground water may not correspond in time to periods of maximum precipitation and runoff. Because of these difficulties, regional meteoric inputs of ${ }^{36} \mathrm{Cl}$ to the hydrogeologic environment at and near the INEEL were estimated by analyzing ground- and surface-water samples collected during 1969-94, and snow and glacial-ice and -runoff samples.

Bentley and others (1986) calculated pre-weapons tests ${ }^{36} \mathrm{Cl} / \mathrm{Cl}$ ratios in meteoric wet and dry precipitation for the continental United States (fig. 4). These calculations were for cosmogenically-produced ${ }^{36} \mathrm{Cl}$ and stable chloride $\left(\mathrm{Cl}^{-}\right)$, principally from transport of sea salts. The preweapons tests ${ }^{36} \mathrm{Cl} / \mathrm{Cl}$ ratios at the latitude of the INEEL average about $450 \times 10^{-15}$ and represent the integrated ratios expected in uncontaminated ground water. For comparison, Cecil and others (1992) reported pre-weapons tests ${ }^{36} \mathrm{Cl} / \mathrm{Cl}$ ratios of about $320 \times 10^{-15}$ for soil in the unsaturated zone near the RWMC at the INEEL. These ratios cannot be changed by evapotranspiration or the addition of chlorine-free water (fig. 5). However, as shown in figure 5 , the absolute concentration of ${ }^{36} \mathrm{Cl}$ can change by these processes. It is assumed that these processes affect the stable isotopes of chlorine in the same way so that even though the absolute concentration of ${ }^{36} \mathrm{Cl}$ can change, the meteoric ratio of ${ }^{36} \mathrm{Cl} / \mathrm{Cl}$ cannot. The ${ }^{36} \mathrm{Cl} / \mathrm{Cl}$ ratios in the glacial-runoff sample, the 2 snow samples and the ground-water samples not affected by INEEL waste disposal, and the 2 spring samples were less than $320 \times 10^{-15}$ (table 1). For comparison, the ${ }^{36} \mathrm{Cl} / \mathrm{Cl}$ ratios in the ground-water samples from a well (USGS 77) at the INEEL affected by waste disposal ranged from $6,180 \pm 90 \times 10^{-15}$, to $10,400 \pm 500 \times 10^{-15}$, or more than two orders of magnitude larger than the meteoric ratios.

Using the ambient $\mathrm{Cl}^{-}$concentration for ground water from the eastern Snake River Plain aquifer of 6 to $10 \mathrm{mg} / \mathrm{L}$ (Robertson and others, 1974) and the average pre-weapons-tests ${ }^{36} \mathrm{Cl} / \mathrm{Cl}$ ratio of 450 $\times 10^{-15}$, the concentration of ${ }^{36} \mathrm{Cl}$ in water should range from 4.6 to $7.6 \times 10^{7}$ atoms $/ \mathrm{L}$. This compares to ranges of measured pre-weapons tests ${ }^{36} \mathrm{Cl}$ concentrations of 1.2 to $5.2 \times 10^{6}$ atoms/ $\mathrm{L}$ for the Upper Fremont Glacier ice core and 4.0 to $6.0 \times$ 


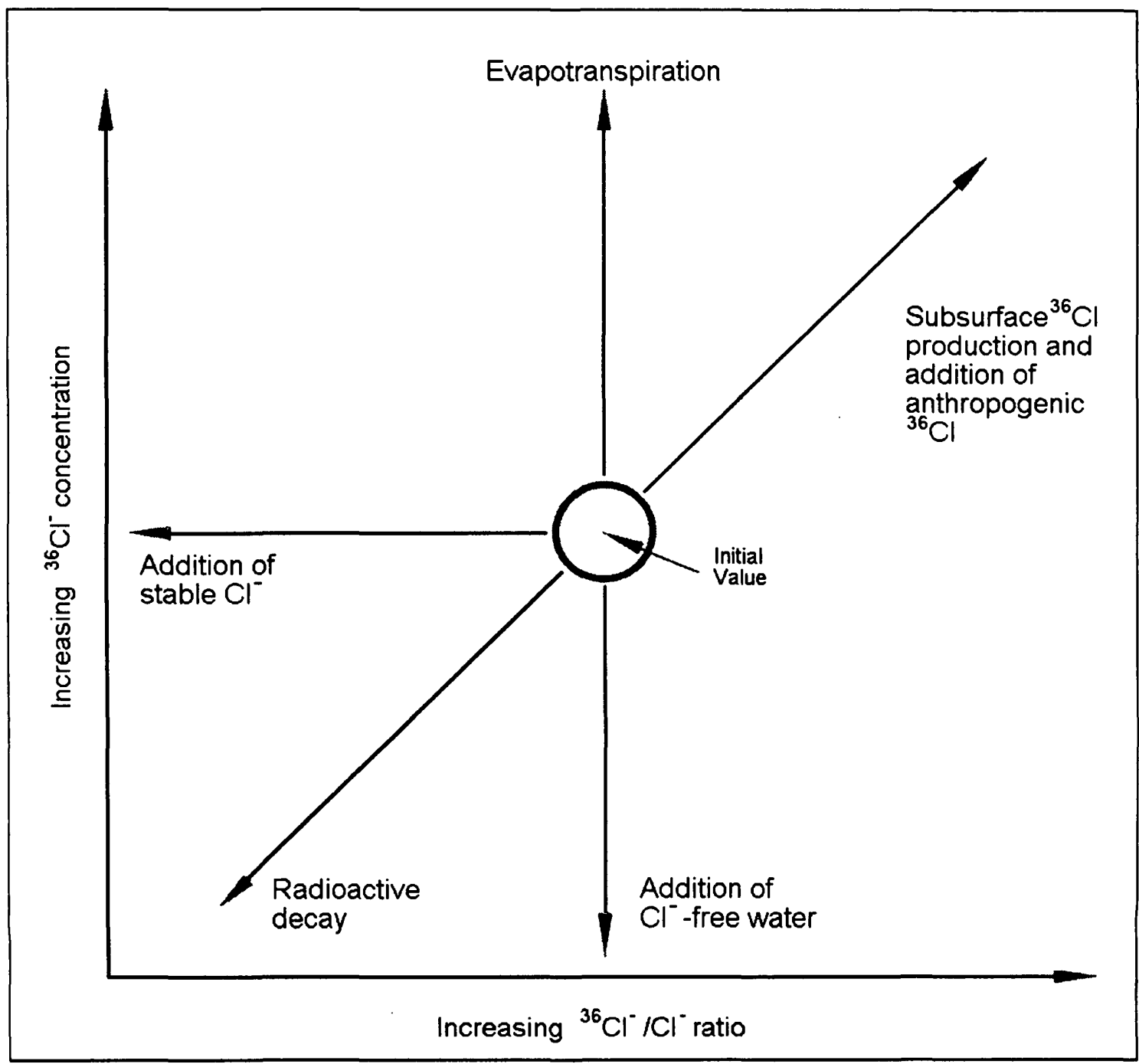

Figure 5. Mechanisms that can change ${ }^{36} \mathrm{Cl}$ concentrations and (or) ${ }^{36} \mathrm{Cl} \mathrm{Cl}$ ratios (modified from Davis and others, 1998). 
$10^{6}$ atoms/L for ground water not affected by INEEL disposal practices (Site 14). This suggests an anthropogenic or in situ component in the ambient $\mathrm{Cl}^{-}$concentrations reported by Robertson and others (1974). Processes that could effect these concentrations are evapotranspiration and the addition of chlorine-free water-Evapotranspiration is a significant process at and near the INEEL, a semi-arid high-plains desert environment. Extensive and long-term irrigation return flow also will affect the absolute concentrations.

The long-term (1980-99) precipitationweighted average $\mathrm{Cl}^{-}$concentration at the National Atmospheric Deposition Program (NADP) station at Craters of the Moon National Monument (fig. 2) near the INEEL is $0.19 \mathrm{mg} / \mathrm{L}$. Using this average chloride concentration and an average pre-weapons tests ${ }^{36} \mathrm{Cl} / \mathrm{Cl}$ ratio of approximately $450 \times 10^{-15}$, the ${ }^{36} \mathrm{Cl}$ concentration in precipitation at the INEEL and vicinity should average about $1.5 \times 10^{6}$ atoms $/ \mathrm{L}$, a value similar to concentrations measured in ground water unaffected by waste disposal (Site 14, table 1). Table 1 lists the concentrations of ${ }^{36} \mathrm{Cl}$ in glacial runoff and snow at nearly the same latitude as the INEEL. These concentrations range from $3.2 \pm 0.5 \times 10^{6}$ to $6.3 \pm 0.9$ $\times 10^{6}$ atoms $/ \mathrm{L}$ again in good agreement with the concentration calculated using the long-term average NADP data for $\mathrm{Cl}^{-}$in precipitation, $1.5 \times 10^{6}$ atoms/L. Concentrations in the 2 snow samples collected at the INEEL during active calcining (conversion of liquid high-level waste into a granular solid) in 1991, INEEL \#1 and INEEL \#2 (table 1), were $14 \pm 0.4 \times 10^{8}$ and $170 \pm 34 \times 10^{8}$ atoms/L respectively. These concentrations are three to four orders of magnitude larger than the concentrations measured in this study for the water, snow, and glacial-ice and -runoff samples unaffected by INEEL waste disposal.

For comparison, 18 surface-water samples from six different sites were selected from the USGS archive-sample library at the INEEL. These 18 samples were collected during the period 1969-94. The ${ }^{36} \mathrm{Cl}$ concentration ranged from $0.2 \pm 0.02 \times 10^{8}$ to $2.2 \pm 0.05 \times 10^{8}$ atoms $/ \mathrm{L}$. In 1994-95, an additional 14 surface-water and 2 spring samples from the eastern Snake River Plain were analyzed for ${ }^{36} \mathrm{Cl}$. The ${ }^{36} \mathrm{Cl}$ concentrations in these samples ranged from $0.014 \pm 0.001 \times 10^{8}$ to $6.2 \pm 0.7 \times 10^{8}$ atoms $/ \mathrm{L}$, a range similar to the range of concentrations in the 18 archived samples. For comparison, ${ }^{36} \mathrm{Cl}$ concentrations in water from two monitoring wells at the INEEL were as large as $0.06 \pm 0.003 \times 10^{8}$ atoms $/ \mathrm{L}$ for the well (site 14 ) not affected by waste disposal and 19,000 $0914 \times 10^{8}$ atoms/L for the well (USGS 77) about $500 \mathrm{~m}$ hydraulically downgradient from the INTEC.

This enrichment in ${ }^{36} \mathrm{Cl}$ concentrations in surface water compared with the calculated and measured meteoric concentrations in precipitation is probably a result of extensive evapotranspiration. The only other mechanism shown in figure 5 that could increase ${ }^{36} \mathrm{Cl}$ concentrations is subsurface (in situ) production. Beasley and others (1993) estimated that the contribution of $3 \times 10^{2}$ atoms $/ \mathrm{L}$ of ${ }^{36} \mathrm{Cl}$ to ground water from this mechanism would produce ${ }^{36} \mathrm{Cl} / \mathrm{Cl}$ ratios on the order of $10^{-18}$. Recent work on possible in situ production from all major rock types in the eastern Snake River Plain aquifer support the conclusion that this mechanism would not have a significant or even measurable effect on ${ }^{36} \mathrm{Cl}$ atom concentrations (Cecil and others, in press).

The largest ${ }^{36} \mathrm{Cl} / \mathrm{Cl}$ ratios from in situ production, on the order of $4 \times 10^{-14}$, correspond to the largest ${ }^{36} \mathrm{Cl}$ concentrations in surface water listed in table 1 and shown on figure 6 . For example, the ${ }^{36} \mathrm{Cl}$ concentration in surface water from Beaver Creek, $6.2 \pm 0.7 \times 10^{8}$ atoms $/ \mathrm{L}$, was the largest in any of the surface water sites; the calculated in situ ratios in rocks from this area range from 2.5 to $3.5 \times 10^{-14}$ (Cecil and others, in press). If all the dissolved chloride in water had been derived from the rocks in this area, this in situ source would contribute at most, $5.9 \times 10^{6}$ atoms $/ \mathrm{L}$. However, the water would have to be on the order of $1.5 \mathrm{mil}$ lion years in age to have this ${ }^{36} \mathrm{Cl}$ concentration. It is highly improbable that surface water would be in contact with the rock matrix for a sufficient amount of time to produce measurable ${ }^{36} \mathrm{Cl}$ concentrations from in situ production. In addition, this concentration is two orders of magnitude less than what has been measured in surface water in this area. This concentration, $6.2 \pm 0.7 \times 10^{8}$ atoms $/ \mathrm{L}$, is probably a result of re-suspension of 


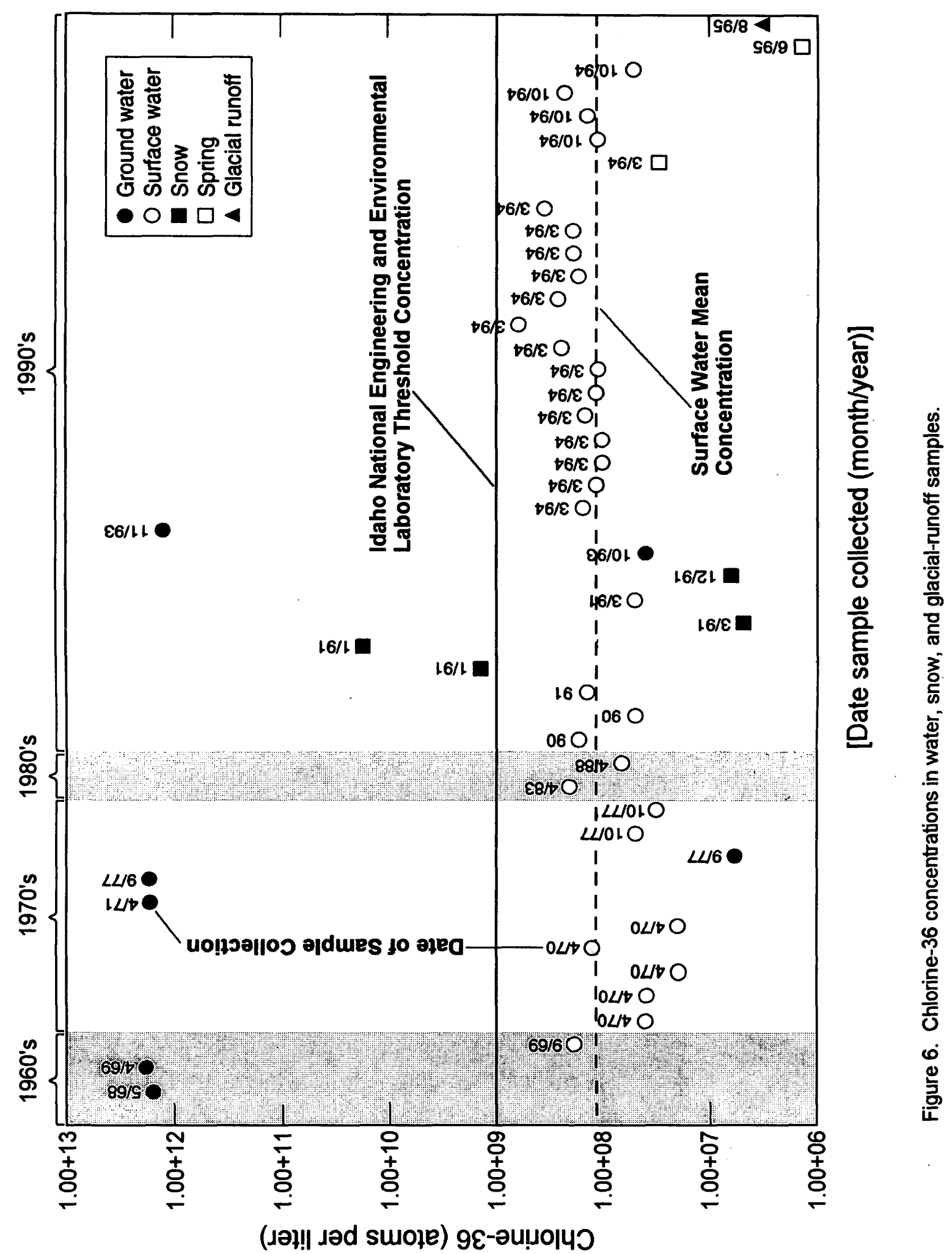


weapons-tests-produced ${ }^{36} \mathrm{Cl}$ and evapotranspiration.

Excluding anthropogenic input of ${ }^{36} \mathrm{Cl}$ to the hydrogeologic environment, the only enriching mechanism is evapotranspiration. The ${ }^{36} \mathrm{Cl} / \mathrm{Cl}$ ratios in the 32 surface-water samples collected during 1969-94 range from $277 \pm 18 \times 10^{-15}$ to $8,300 \pm 970 \times 10^{-15}$ (table 1), or more than an order of magnitude. Excluding the 2 snow samples collected during mixed-waste calcining at the INTEC and the glacial-runoff and snow samples shown in figure 6 , all the surface-water concentrations are scattered about the line representing $1.5 \times 10^{8}$ atoms/L, the mean concentration for the 32 surface-water samples. This distribution may be representative of evaporative processes in these surface-water samples. Evidence of evaporative processes affecting deuterium and oxygen isotopic ratios in surface water from the Snake River Plain aquifer system also has been reported (Wood and Low, 1988, p. D15). The ${ }^{36} \mathrm{Cl}$ concentrations between $1 \times 10^{8}$ and $1 \times 10^{9}$ atoms $/ \mathrm{L}$ on figure 6 may be indicative of re-suspension of weapons-test fallout, airborne disposal of ${ }^{36} \mathrm{Cl}$ from the INTEC, or evapotranspiration.

Another useful geochemical selection criterion for determining meteoric ${ }^{36} \mathrm{Cl}$ inputs is the chloride/bromide $\left(\mathrm{Cl}^{-} / \mathrm{Br}^{-}\right)$mass ratio (Davis and others, 1998). For precipitation, this ratio is generally in the range of 80 to 160 . Ratios in many oil-field brines range from 250 to 350 , and ratios in brines produced from the dissolution of bedded salt and salt domes range from 1,500 to 15,000 . Exceptions include ratios in precipitation within a few tens of kilometers from the coastline which may approach 290 , the ratio in seawater. For determining meteoric ${ }^{36} \mathrm{Cl}$ concentrations, ratios in excess of 200 indicate chloride sources other than precipitation, therefore, these waters should be avoided for determining meteoric inputs.

Water from several of the surface-water sites, from Big Spring, and from the glacial-runoff sample were analyzed for chloride and bromide. Using the criterion outlined above, the results for this limited analysis of $\mathrm{Cl}^{-} / \mathrm{Br}^{-}$mass ratios indicate that only the water from Big Spring and from the glacial-runoff sample is suitable for quantifying meteoric ${ }^{36} \mathrm{Cl}$ inputs at and near the INEEL (table 4). The ${ }^{36} \mathrm{Cl}$ concentrations in water from Big Spring and the glacial-runoff sample are less than $1 \times 10^{7}$ atoms $/ L$ and represent meteoric inputs on the eastern Snake River Plain. These results indicate the addition of chloride from sources other than meteoric to all the surface water samples. The ${ }^{36} \mathrm{Cl} / \mathrm{Cl}$ ratios and concentrations given in table 1 and on figure 6 also indicate enrichment of chloride in these samples. Additional work is necessary to establish the $\mathrm{Cl}^{-} / \mathrm{Br}^{-}$mass ratios for the glacial-ice samples. The bromide analyses listed in table 4 have an associated uncertainty of 25 percent assigned by the laboratory.

Table 4. Mass ratios of chloride/bromide for selected surface-water samples and a glacial-runoff sample. (See figs 1 and 3 for site locations; see text for explaination of uncertainties).

[mg/L, milligrams per liter; $\mathrm{Cl} / \mathrm{Br}$, chloride/bromide; SW, surface water; and $\mathrm{GR}$, glacial runoff]

\begin{tabular}{ccccc}
\hline Site or sample identifier & $\begin{array}{c}\text { Date of } \\
\text { sample }\end{array}$ & $\begin{array}{c}\text { Chloride } \\
\text { content } \\
(\mathbf{m g} / \mathbf{L})\end{array}$ & $\begin{array}{c}\text { Bromide } \\
\text { content } \\
(\mathbf{m g} / \mathbf{L}) \\
\pm 25 \text { percent }\end{array}$ & $\begin{array}{c}\mathrm{Cl}^{-/ \mathbf{B r}^{-}} \\
\text {Mass ratio }\end{array}$ \\
\hline Big Spring-SW & $6-27-95$ & $2.6 \pm 0.4$ & $0.02 \pm 0.005$ & 130 \\
Big Lost River-SW & $6-28-95$ & $2.3 \pm 0.4$ & $0.006 \pm 0.002$ & 383 \\
Birch Creek-SW & $6-28-95$ & $4.8 \pm 0.5$ & $0.007 \pm 0.002$ & 686 \\
Camas Creek-SW & $6-28-95$ & $2.5 \pm 0.4$ & $0.006 \pm 0.002$ & 417 \\
Little Lost River-SW & $6-28-95$ & $23 \pm 9$ & $0.044 \pm 0.011$ & 523 \\
Galena Creek Rock Glacier-GR & $8-30-95$ & $0.079 \pm 0.004$ & $0.0015 \pm 0.0004$ & 53 \\
\hline
\end{tabular}




\section{WEAPONS-TESTS INPUT}

The calculated ${ }^{36} \mathrm{Cl}$ concentrations in the sections of the Upper Fremont Glacier ice core are of similar magnitude to those in Arctic and Antarctic ice cores (Elmore and others, 1982; Synal and others, 1991). Concentrations of a few million atoms per liter (water equivalent of ice) are typical values for pre- and post-weapons-tests ${ }^{36} \mathrm{Cl}$ concentrations (fig. 7). A direct comparison, however, between the polar results and the mid-latitude results should be made with caution because the ${ }^{36} \mathrm{Cl}$ flux depends on the precipitation rate which can vary considerably from one geographic location to another. Complex atmospheric dynamics also may contribute to larger fallout of cosmogenic nuclides at mid-latitudes when compared to polar regions because of stratospheric-tropospheric air exchange mechanisms (Baltensperger and others, 1993).

However, a more quantitative comparison between mid-latitude results and modern ${ }^{36} \mathrm{Cl}$ deposition over the continental United States can be made with some confidence. Knies and others (1994) reported an average ${ }^{36} \mathrm{Cl}$ concentration in precipitation of $1.7 \times 10^{6}$ atoms $/ \mathrm{L}$, the volumeweighted average from measurements of all significant precipitation events during April 1992 and August 1993 in central Indiana. Similar ${ }^{36} \mathrm{Cl}$ concentrations in wet precipitation were reported by Hainsworth and others (1994) for the east coast of the United States; the average for the period from February 1991 to January 1993 was $1.7 \pm 0.2 \times 10^{6}$ atoms $/ \mathrm{L}$. These ${ }^{36} \mathrm{Cl}$ concentrations in precipitation are similar to the ${ }^{36} \mathrm{Cl}$ concentrations measured in the pre- and post-weapons-tests sections of the Upper Fremont Glacier ice core; $1.2 \pm 0.2 \times 10^{6}$ to $5.2 \pm 0.4 \times 10^{6}$ atoms $/ \mathrm{L}$ (table 2 ). These concentrations are similar to concentrations in the 2 snow samples collected near the INEEL in 1991 and the glacial-runoff sample from the Galena Creek Rock Glacier collected in 1995. The ${ }^{36} \mathrm{Cl}$ concentration in the Harriman State Park snow sample was $6.3 \pm 0.9 \times 10^{6}$ atoms $/ \mathrm{L}$; the calculated concentration in the Copper Basin snow sample was $4.9 \pm 2.5 \times 10^{6}$ atoms $/ \mathrm{L}$, and the concentration in the Galena Creek Rock Glacier runoff sample was $3.2 \pm 0.5 \times 10^{6}$ atoms $/ \mathrm{L}$ (table 1 ). The concentration of ${ }^{36} \mathrm{Cl}$ in the snow sample from
Copper Basin was used here for comparison purposes even though this concentration, $4.9 \pm 2.5 \times$ $10^{6}$ atoms $/ \mathrm{L}$, has a 50 percent associatied uncertainty.

Mean wet-only precipitation fluxes of ${ }^{36} \mathrm{Cl}$ determined in these studies were $6.79 \pm 0.47 \times 10^{-3}$ atoms $/ \mathrm{cm}^{2} \mathrm{sec}$ (Knies and others, 1994), $3.86 \pm 0.54 \times 10^{-3}$ atoms $/ \mathrm{cm}^{2} \mathrm{sec}$ (Hainsworth and others, 1994), and $8.28 \pm 0.91 \times 10^{-3}$ atoms $/ \mathrm{cm}^{2} \mathrm{sec}$ for pre- and post-weapons-tests flux for ice from the Upper Fremont Glacier. The wet-precipitation-only flux determined in the central and the western United States appears to be about a factor of two larger than the flux for the eastern United States at similar latitudes. The mean flux for the Upper Fremont Glacier site was determined by averaging the values in table 2 for samples collected at depths less than $24.0 \mathrm{~m}$ and greater than $46.4 \mathrm{~m}$ in depth; this minimized the contribution of fallout from nuclear-weapons tests in the 1950-60's. The resulting mean flux was then reduced by 30 percent to account for dry deposition of ${ }^{36} \mathrm{Cl}$ (Hainsworth and others, 1994). The mean flux for the 2 snow samples collected near the INEEL in 1991 was $7.5 \pm 0.2 \times 10^{-3}$ atoms $/ \mathrm{cm}^{2} \mathrm{sec}$. Estimated flux for the glacial runoff sample was $16 \pm 2 \times 10^{-3}$ atoms $/ \mathrm{cm}^{2} \mathrm{sec}$. The average precipitation rates used to calculate the fluxes for the snow samples and the Galena Creek Rock Glacier runoff sample were: (1) $58 \mathrm{~cm} /$ year for Harriman State Park (L.L. Jones, Idaho Department of Parks and Recreation, oral commun., 1996); (2) $22 \mathrm{~cm} /$ year for INEEL \#1 and \#2 (Clawson and others, 1989); (3) $18 \mathrm{~cm} /$ year for Copper Basin (Steven M. Spencer, U.S. Forest Service, written commun., 1996); and (4) 160 $\mathrm{cm} /$ year for Galena Creek Rock Glacier runoff (estimated from data for the Upper Fremont Glacier site, includes accumulation and ablation). The precipitation rates used in calculated ${ }^{36} \mathrm{Cl}$ flux for the 4 snow samples did not include evapotranspiration. Therefore, these calculated fluxes should be considered as maximum and may be reduced by as much as 95 percent due to evapotranspiration (Cecil and others, 1992).

In a detailed discussion of the pre- and post-weapons tests ${ }^{36} \mathrm{Cl}$ concentrations in the Upper Fremont Glacier ice core, more subtle 


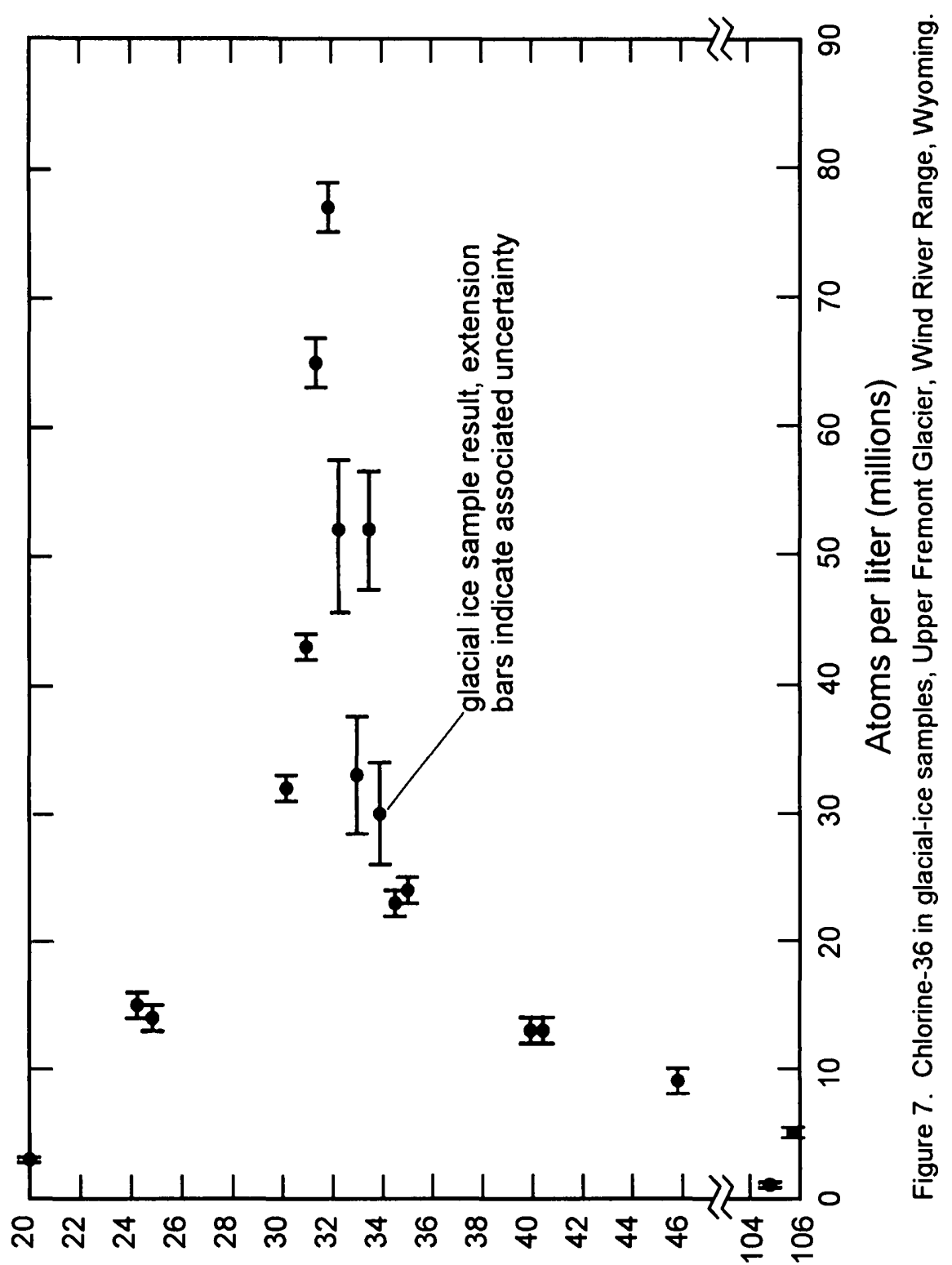

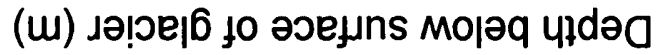


effects such as dry deposition of ${ }^{36} \mathrm{Cl}$, seasonal effects, and thawing/freezing cycles of the upper ice layer may play important roles. For instance, the total wet and dry ${ }^{36} \mathrm{Cl}$ flux determined by Hainsworth and others (1994), was $5.85 \pm 0.78 \times 10^{-3}$ atoms $/ \mathrm{cm}^{2} \mathrm{sec}$. Calculated ${ }^{36} \mathrm{Cl}$ fluxes derived from the Upper Fremont Glacier ice core are also of similar magnitude: $4.5 \pm 0.7 \times 10^{-3}$ to $20 \pm 2 \times 10^{-3}$ atoms $/ \mathrm{cm}^{2} \mathrm{sec}$ (table 2). Hainsworth and others (1994) showed that the dry deposition of ${ }^{36} \mathrm{Cl}$ can account for about 30 percent of the total input as inferred from a direct comparison of analyses performed on samples collected in open (for dry deposition) and wet-only collectors. Significant seasonal effects on ${ }^{36} \mathrm{Cl}$ and other cosmogenic nuclide deposition were reported by Knies and others (1994). In addition, recurring thawing/freezing events that result in downward percolation of meltwater in the ice core stratigraphy will obscure any seasonal or other cyclic event represented in the ice. All these variables might play a role in the fine structure of the results. However, these factors are of no immediate concern to the proper interpretation of the results presented in this report as evidenced by data discussed later and by the results of related studies such as Naftz and others (1991).

Naftz and others (1991) reported on a reconnaissance study to determine the relation among concentrations of select chemical species dissolved in wet precipitation and concentrations of the same species dissolved in annual ice layers collected from the Knife Point Glacier in Wyoming's Wind River Range (fig. 1). Knife Point Glacier is about $1 \mathrm{~km}$ southeast from the Upper Fremont Glacier. Constituent concentrations calculated from annual-weighted means of wet-deposition samples from the NADP station near Pinedale (fig. 1) for the years 1982-87, were compared with concentrations in the annual ice layers (fig. 8). The chloride concentration in the deposition samples and in the corresponding ice layers showed a significant correlation coefficient of 0.98 indicating that for determining chloride concentrations, some of the mid-latitude glaciers from the Wind River Range may not be subject to severe meltwater contamination. Additionally, these data indicate that the annual ice layers may provide a reliable long-term record of at least a portion of the chemical composition of precipitation.

However, as shown in figure 8 , the dissolved-chloride concentrations in the annual ice layers at Knife Point Glacier were consistently larger than the concentrations calculated from annual-weighted means of wet-deposition samples from the NADP station near Pinedale. This is further evidence that dry deposition of chloride may affect the dissolved-chloride concentrations in precipitation and ice, as reported by Hainsworth and others (1994).

Long-term records of accumulation and ablation of snow, firn, and ice were not available for the Upper Fremont Glacier ice-core location. Therefore, accumulation and ablation were calculated according to the following method to estimate a total average annual precipitation flux for this site. An average annual accumulation flux of $80 \mathrm{~g} / \mathrm{cm}^{2}$ yr was calculated using average core densities reported by Naftz (1996, written communication) of $0.65 \mathrm{~g} / \mathrm{cm}^{3}$ for the 0 - to 14 -m-deep section and $0.89 \mathrm{~g} / \mathrm{cm}^{3}$ for the remaining core down to the measured weapons-tests-produced ${ }^{3} \mathrm{H}$ peak at $29 \mathrm{~m}$. An average annual accumulation flux of $76 \mathrm{~g} / \mathrm{cm}^{2} \mathrm{yr}$ was calculated using these same densities down to the depth of the measured ${ }^{36} \mathrm{Cl}$ peak at about $32 \mathrm{~m}$. This calculated average annual accumulation flux was in good agreement with the flux determined from the ${ }^{3} \mathrm{H}$ peak.

Additionally, to account for all ${ }^{36} \mathrm{Cl}$ deposited at this high-altitude mid-latitude site, ablation of snow, firn, and ice also was considered in the total average annual precipitation flux for this study. Naftz and others (1996) reported an average ablation at five sites on the Upper Fremont Glacier of $93 \mathrm{~cm} / \mathrm{yr}$ during 1990-1991. This ablation rate is similar to the average ablation of $88 \mathrm{~cm} /$ year (Marston and others, 1991) on the Dinwoody Glacier during 1958-83. Dinwoody Glacier is approximately $5 \mathrm{~km}$ north of the Upper Fremont Glacier and is at the same altitude.

Using the $88 \mathrm{~cm} / \mathrm{yr}$ average annual ablation rate and an assumed density for ablated snow, firn, and ice of $0.5 \mathrm{~g} / \mathrm{cm}^{3}$, the average annual precipitation flux lost was estimated at $44 \mathrm{~g} / \mathrm{cm}^{2} \mathrm{yr}$. The accumulated precipitation flux calculated from the 


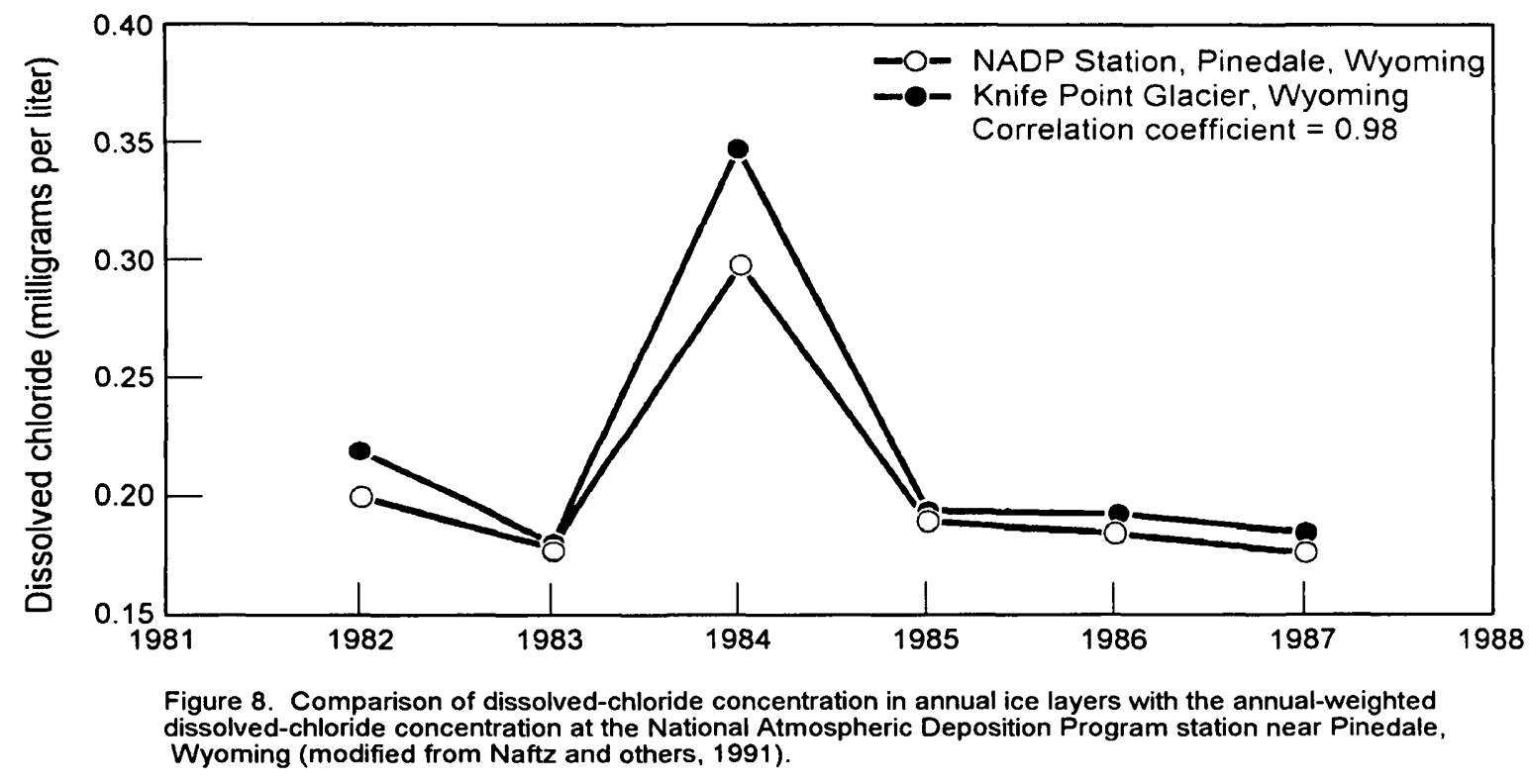


${ }^{36} \mathrm{Cl}$ weapons-tests peak at $32 \mathrm{~m}$ depth was $76 \mathrm{~g} / \mathrm{cm}^{2} \mathrm{yr}$. Considering accumulation and ablation, the combined average annual precipitation flux for the Upper Fremont Glacier ice-core location was approximately $120 \mathrm{~g} / \mathrm{cm}^{2} \mathrm{yr}$.

This estimated average annual precipitation flux and the measured ${ }^{36} \mathrm{Cl}$ concentrations in atoms/g of ice (table 2) were used to calculate ${ }^{36} \mathrm{Cl}$ fluxes. These ${ }^{36} \mathrm{Cl}$ fluxes are a first approximation only and are based on the estimated precipitation flux as described above. Estimated fluxes for the 10 sections of ice between 29.8 and $35.3 \mathrm{~m}$ in depth range from $9.0 \pm 0.2 \times 10^{-2}$ to $2.9 \pm 0.1 \times 10^{-1}$ atoms $/ \mathrm{cm}^{2} \mathrm{sec}$ (table 2). These fluxes are up to two orders of magnitude larger than the mean global natural-production flux for ${ }^{36} \mathrm{Cl}\left(1.1 \times 10^{-3}\right.$ atoms $/ \mathrm{cm}^{2} \mathrm{sec}$; Lal and Peters, 1967) and compared well with the weapons-tests flux reported by Elmore and others (1982) of $5 \times 10^{-1}$ atom $/ \mathrm{cm}^{2} \mathrm{sec}$ for the Dye 3 ice core from Greenland, deposited during the same period of time as the Upper Fremont Glacier ice. The continuous section of ice core between 29.8 and $35.3 \mathrm{~m}$ represents the minimum ${ }^{36} \mathrm{Cl}$ produced by nuclear-weapons tests in the 1950-60's deposited at this site for reasons described earlier.

Sections of ice selected to represent pre-weapons-tests ${ }^{36} \mathrm{Cl}$ flux were centered at depths of $105.1 \mathrm{~m}$ and $105.9 \mathrm{~m}$; the estimated fluxes were $4.5 \pm 0.7 \times 10^{-3}$ and $2.0 \pm 0.2 \times 10^{-2}$ atoms $/ \mathrm{cm}^{2} \mathrm{sec}$, respectively. It is not understood at this time why the calculated flux of the section of ice centered at a depth of $105.9 \mathrm{~m}$ was nearly five times larger than the reported mean global average. The section of ice centered at $20.5 \mathrm{~m}$ had a calculated ${ }^{36} \mathrm{Cl}$ flux of $1.1 \pm 0.2 \times 10^{-2}$ atoms $/ \mathrm{cm}^{2} \mathrm{sec}$ and is representative of post-weapons-tests fluxes. The sections of ice between 39.6 and $46.4 \mathrm{~m}$ had a range of calculated ${ }^{36} \mathrm{Cl}$ fluxes from $3.9 \pm 0.5 \times 10^{-2}$ to $5.3 \pm 0.1 \times 10^{-2}$ atoms $/ \mathrm{cm}^{2} \mathrm{sec}$ and most likely had a component of weapons-tests-produced ${ }^{36} \mathrm{Cl}$. Additionally, the 2 sections of ice centered at 24.25 and $24.75 \mathrm{~m}$ had calculated ${ }^{36} \mathrm{Cl}$ fluxes of $6.3 \pm 0.3 \times 10^{-2}$ and $5.4 \pm 0.2 \times 10^{-2}$ atoms $/ \mathrm{cm}^{2} \mathrm{sec}$ respectively; these fluxes also probably had a component of weapons-tests-produced ${ }^{36} \mathrm{Cl}$.

In terms of concentrations in water equivalent, the largest value for weapons-tests-produced ${ }^{36} \mathrm{Cl}$ identified in the Upper Fremont Glacier ice core was $7.7 \pm 0.2 \times 10^{7}$ atoms/L (table 2 and fig. 7 ). This concentration is more than an order of magnitude larger than the meteoric concentration in water from Big Spring $\left(1.4 \pm 0.1 \times 10^{6}\right.$ atoms $\left./ \mathrm{L}\right)$, Galena Creek Rock Glacier $\left(3.2 \pm 0.5 \times 10^{6}\right.$ atoms/L), the snow samples at Harriman State Park and Copper Basin $\left(6.3 \pm 0.9 \times 10^{6}\right.$ and $4.9 \pm 2.5$ $\times 10^{6}$ atoms $/ \mathrm{L}$, respectively), and the calculated long- term average concentration in precipitation at the Craters of the Moon NADP station (1.5 x $10^{6}$ atoms $/ \mathrm{L}$ ). This concentration is about 1.5 to 2.5 orders of magnitude smaller than the concentrations in the 2 snow samples (INEEL \#1, \#2; table 1) collected during calcining operations at the INEEL and is nearly six orders of magnitude smaller than the concentrations in ground water from USGS 77 near the INTEC (table 1). All concentrations of ${ }^{36} \mathrm{Cl}$ in ice samples processed from the Upper Fremont Glacier plot below the $1 \times 10^{8}$ atoms $/ \mathrm{L}$ line in figure 6 . The results of the ${ }^{36} \mathrm{Cl}$ analyses from the ground- and surface-water, snow, and glacial-ice and -runoff samples suggest that only concentrations larger than $1 \times 10^{9}$ atoms $/ \mathrm{L}$ measured in the environment at the INEEL can be attributed to waste disposal at the site. Additionally, concentrations in water, snow, or glacial ice between $1 \times 10^{7}$ and $1 \times 10^{8}$ atoms $/ \mathrm{L}$ may be indicative of a weapons-tests component from peak ${ }^{36} \mathrm{Cl}$ production in the late 1950 s.

\section{SUMMARY AND CONCLUSIONS}

To facilitate the use of chlorine- $36\left({ }^{36} \mathrm{Cl}\right)$ as a hydrogeologic tracer at the INEEL, measurements were made on 64 water, snow, and glacial-ice and -runoff samples to determine the meteoric- and weapons-tests-produced concentrations and fluxes of ${ }^{36} \mathrm{Cl}$ at mid-latitudes in North America. This information was used to estimate meteoric- and weapons-tests contributions of this nuclide to environmental inventories at and near the INEEL.

Eighteen surface-water samples from six sites were selected from the USGS archive-sample library at the INEEL for ${ }^{36} \mathrm{Cl}$ analyses. These 18 samples had been collected during the period 1969-94. The ${ }^{36} \mathrm{Cl}$ concentrations for the archived surface-water samples ranged from $0.2 \pm 0.02 \times 10^{8}$ to $2.2 \pm 0.05 \times 10^{8}$ atoms/L. In 1994-95, an addi- 
tional 14 surface-water and 2 spring samples from the eastern Snake River Plain were collected and analyzed for ${ }^{36} \mathrm{Cl}$. The ${ }^{36} \mathrm{Cl}$ concentrations ranged from $0.014 \pm 0.001 \times 10^{8}$ to $6.2 \pm 0.7 \times 10^{8}$ atoms $/ \mathrm{L}$, a range similar to that of concentrations in the 18 archived samples. For comparison, ${ }^{36} \mathrm{Cl}$ concentrations in water from two monitoring wells at the INEEL were as large as $0.06 \pm 0.003 \times 10^{8}$ atoms $/ \mathrm{L}$ for the well (site 14) not affected by waste disposal and $19,000 \pm 914 \times 10^{8}$ atoms $/ \mathrm{L}$ for the well (USGS 77) about $500 \mathrm{~m}$ hydraulically downgradient from the INTEC.

To aid in establishing meteoric concentrations, 4 snow samples were collected in 1991 at and near the INEEL. The ${ }^{36} \mathrm{Cl}$ concentrations in the snow samples ranged nearly four orders of magnitude, from $6.3 \pm 0.9 \times 10^{6}$ to $1.7 \pm 0.3 \times 10^{10}$ atoms $/ \mathrm{L}$. The estimated ${ }^{36} \mathrm{Cl}$ flux for the sample collected in Harriman State Park, $150 \mathrm{~km}$ northeast of the INEEL, was $1.2 \pm 0.2 \times 10^{-2}$ atoms $/ \mathrm{cm}^{2} \mathrm{sec}$. The estimated ${ }^{36} \mathrm{Cl}$ flux for the sample collected in Copper Basin, $75 \mathrm{~km}$ west of the INEEL, was $3 \pm 2$ $\times 10^{-3}$ atoms $/ \mathrm{cm}^{2} \mathrm{sec}$. For comparison, 2 snow samples were collected at the INEEL downwind from the INTEC during calcining operations. The estimated ${ }^{36} \mathrm{Cl}$ flux for the sample collected $11 \mathrm{~km}$ southwest of the effluent stack at the INTEC was $1.0 \pm 0.03$ atoms $/ \mathrm{cm}^{2} \mathrm{sec}$ and for the sample $1.5 \mathrm{~km}$ downwind, the flux was $12.0 \pm 2.4$ atoms $/ \mathrm{cm}^{2} \mathrm{sec}$.

A $160-\mathrm{m}$ ice core was collected in 1991 from the Upper Fremont Glacier in the Wind River Mountain Range of Wyoming in the western United States. In 1994-95, ice from this core was processed at the National Ice Core Laboratory in Denver, Colorado, and analyzed for ${ }^{36} \mathrm{Cl}$. The peak ${ }^{36} \mathrm{Cl}$ concentration in ice deposited as snow during atmospheric weapons tests was $7.7 \pm 0.2 \times 10^{7}$ atoms $/ \mathrm{L}$ at a depth of about $32 \mathrm{~m}$ below the glacial surface. Estimated flux for ${ }^{36} \mathrm{Cl}$ in ice deposited in the 1950's during peak weapons-tests production ranged from $9.0 \pm 0.2 \times 10^{-2}$ atoms $/ \mathrm{cm}^{2} \mathrm{sec}$ for a sample from a depth of 34.2 to $34.8 \mathrm{~m}$ to $2.9 \pm 0.1 \times 10^{-1}$ atoms $/ \mathrm{cm}^{2} \mathrm{sec}$ for a sample from a depth of 31.5 to $32.0 \mathrm{~m}$.

Ice samples from depths of 19.6 to $25.0 \mathrm{~m}, 39.6$ to $46.4 \mathrm{~m}$, and 104.7 to $106.3 \mathrm{~m}$ were selected to represent pre- and post-weapons tests ${ }^{36} \mathrm{Cl}$ concentrations and fluxes. The concentrations in the pre- and post-weapons sections of glacial ice and runoff were less than $2 \times 10^{7}$ atoms $/ \mathrm{L}$. The estimated fluxes for ${ }^{36} \mathrm{Cl}$ in these cores ranged from $4.5 \pm 0.7$ $\times 10^{-3}$ atoms $/ \mathrm{cm}^{2} \mathrm{sec}$ to $6.3 \pm 0.3 \times 10^{-2}$ atoms $/ \mathrm{cm}^{2} \mathrm{sec}$. For comparison, a flux of $1.6 \pm 0.2 \times$ $10^{-2}$ was estimated for a glacial-runoff sample collected in 1995 at Galena Creek Rock Glacier, 180 $\mathrm{km}$ north of the Upper Fremont Glacier.

A mean global-natural-production flux for ${ }^{36} \mathrm{Cl}$ of $1.1 \times 10^{-3}$ atoms $/ \mathrm{cm}^{2} \mathrm{sec}$ was reported. This flux is similar to the calculated flux for the section of ice centered at $105.1 \mathrm{~m}$ of depth that was selected to be representative of pre-weapons-tests ${ }^{36} \mathrm{Cl}$. It is not understood at this time why the calculated flux of the ice section centered at $105.9 \mathrm{~m}$ of depth was nearly five times larger than the reported mean global average. The largest calculated flux from this study was for the section of ice centered at $31.8 \mathrm{~m}$ of depth; $2.9 \pm 0.1 \times 10^{-1}$ atoms $/ \mathrm{cm}^{2} \mathrm{sec}$. This flux is two orders of magnitude larger than the mean global-natural-production flux and is similar to the reported weapons flux of $5 \times 10^{-1}$ atoms $/ \mathrm{cm}^{2}$ sec for the Dye 3 ice core from Greenland, deposited during the same period of time as the Upper Fremont Glacier ice.

For the first time, ${ }^{36} \mathrm{Cl}$ concentrations and fluxes from weapons-tests production have been identified and estimated for a mid-latitude North American ice core. Only a portion of the weapons-tests-produced ${ }^{36} \mathrm{Cl}$ peak has been identified in ice from the Upper Fremont Glacier in Wyoming's Wind River Range. The measured ${ }^{36} \mathrm{Cl}$ concentrations in the ice core from the Upper Fremont Glacier complement the measured ${ }^{3} \mathrm{H}$ concentrations, and are similar to the results of weapons-testsproduced ${ }^{36} \mathrm{Cl}$ in polar ice and ice in Greenland. It may now be possible to fully quantify the concentrations and fluxes of ${ }^{36} \mathrm{Cl}$ from nuclear-weapons tests archived in mid-latitude glacial ice and to gain a better understanding of the distribution at mid-latitude of ${ }^{36} \mathrm{Cl}$ and other cosmogenic nuclides. The data presented in this report suggest a meteoric source of ${ }^{36} \mathrm{Cl}$ for environmental samples collected in southeastern Idaho and western Wyoming if the concentration is less than $1 \times 10^{7}$ atoms $/ \mathrm{L}$. Additionally, concentrations in water, snow, or glacial ice between $1 \times 10^{7}$ and $1 \times 10^{8}$ atoms $/ \mathrm{L}$ may be indicative of a weapons-tests 
component from peak ${ }^{36} \mathrm{Cl}$ production in the late 1950s. Chlorine- 36 concentrations between $1 \times$ $10^{8}$ and $1 \times 10^{9}$ atoms $/ \mathrm{L}$ may be representative of re-suspension of weapons-tests fallout, airborne disposal of ${ }^{36} \mathrm{Cl}$ from the INTEC, or evapo- transpiration. It was concluded from the ground- and surface-water, snow, glacial-ice and -runoff data presented here that only concentrations larger than $1 \times 10^{9}$ atoms $/ \mathrm{L}$ measured in the environment at the INEEL can be attributed to waste disposal at the site.

\section{REFERENCES}

Ackerman, D.J., 1991, Transmissivity of the Snake River Plain aquifer at the Idaho National Engineering Laboratory, Idaho: U.S. Geological Survey Water-Resources Investigations Report 91-4058 (DOE/ID-22097), 35 p.

Baltensperger, U., Schwikowski, M., Gaggeler, H.W., Jost, D.T., Beer, J., Siegenthaler, U., Wagenbach, D., Hofmann, H.J., and Synal, H.A., 1993, Transfer of atmospheric constituents into an alpine snowfield: Atmospheric Environment, vol. 27A, no. 12, p. 1881-1890.

Beasley, T.M., Cecil, L.D., Sharma, P., Kubik, P.W., Fehn, U., Mann, L.J., and Gove, H.E., 1993, Chlorine-36 in the Snake River Plain Aquifer at the Idaho National Engineering Laboratory-Origin and Implications: Ground Water, vol. 31, no. 2, p. 302-310.

Bentley, H.W., Phillips, F.W., and Davis, S.N., 1986, Chlorine-36 in the terrestrial environment: In Handbook of Environmental Isotopes, vol. 2, p. 422-480, Fritz P., and Fontes J-C., eds.: Elsevier, New York.

Cecil, L.D., Beasley, T.M., Pittman, J.R., Michel, R.L., Kubik, P.W., Sharma, P., Fehn, U., and Gove, H.E., 1992, Water infiltration rates in the unsaturated zone at the Idaho National Engineering Laboratory from chlorine-36 and tritium profiles, and neutron logging: In Water-Rock Interactions, by Kharaka, Y.F., and Maest, A.S., eds.: , A.A. Balkema, Rotterdam, vol. 1, p. 709-714.

Cecil, L.D., and Vogt, S., 1997, Identification of bomb-produced chlorine- 36 in mid-latitude glacial ice of North America: Nuclear Instruments and Methods in Physics Research, vol. B123, p. 287-289.

Cecil, L.D., Green, J.R., Vogt S., Michel R., and Cottrell G., 1998, Isotopic Composition of Ice Cores and Meltwater from Upper Fremont Glacier and Galena Creek Rock Glacier, Wyoming: Geografiska Annaler, Vol. 80A, p. 287-292.

Cecil, L.D., Knobel, L.L., Green, J.R., and Frape, S.K., (in press), In situ production of chlorine-36 in the eastern Snake River Plain aquifer near the Idaho National Engineering and Environmental Laboratory.

Clawson, K.L., Start, G.E., and Ricks, N.R., eds, 1989, Climatography of the Idaho National Engineering Laboratory: U.S. Department of Commerce, National Oceanic and Atmospheric Administration, DOE/ID-12118, 155 p.

Davis, S.N., Cecil, L.D., Zareda, M., and Sharma, P., (1998). Chlorine-36 and the initial value problem; In Hydrogeology Journal: Springer-Verlag, vol. 6, no.1, p. $104-114$.

Elmore, D., Fulton, B.R., Clover, M.R., Marsden, J.R., Gove, H.E., Naylor, H., Purser, K.H., Kilius, L.R., Beukens, R.P., and Litherland, A.E., 1979 , Analysis of ${ }^{36} \mathrm{Cl}$ in environmental water samples using an electrostatic accelerator: Nature, v. 127, p 22-25.

Elmore, D., Tubbs, L.E., Newman, D., Ma, X.Z., Finkel, R., Nishiizumi, K., Beer, J., Oeschger, H., and Andree, M., 1982, ${ }^{36} \mathrm{Cl}$ bomb pulse measured in a shallow ice core from Dye 3, Greenland: Nature, v. 300 , no. 5894 , p. 735-737.

Eriksson, E., 1960, The yearly circulation of chloride and sulfur in nature, II-meteorological, geochemical, and pedological implications: Tellus, 12: 63-109.

Finkel, R.C., Nishiizumi, K., Elmore, D., Ferraro, R.D., and Gove, H.E., $1980,{ }^{36} \mathrm{Cl}$ in polar ice, rainwater and seawater: Geophysical Research Letters, v. 7, no. 11, p. 983-986. 
Fishman, M.J., and Friedman, L.C., eds, 1989, Methods for determination of inorganic substances in water and fluvial sediments: U.S. Geological Survey Techniques of Water-Resources Investigations, 3rd ed., book 5, Chap. A1, 545 p.

Hainsworth, L.J., Mignerey, A.C., Helz, G.R., Sharma, P., and Kubik, P.W., 1994, Modern chlorine-36 deposition in southern Maryland, U.S.A.: Nuclear Instruments and Methods in Physics Research, B 92: Elsevier Science, Holland, p. 345-349.

Knies, D.L., Elmore, D., Sharma, P., Vogt, S., Li, R., Lipschutz, M.E., Petty, G., Farrel, J., Monaghan, M.C., Fritz, S., and Agee, E., 1994, ${ }^{7} \mathrm{Be},{ }^{10} \mathrm{Be},{ }^{36} \mathrm{Cl}$ in precipitation: Nuclear Instruments and Methods in Physics Research, vol. B92, p. 340-344.

Lal, D., and Peters, B., 1967, Cosmic ray produced radioactivity in the earth: In Handbuch der Physik, 46/2, ed., Sitte, K.: Springer, Berlin, p. 551-612.

Lucey, K.J., 1990, QADATA user's manual-An interactive computer program for the retrieval and analysis of the results from the external blind sample quality-assurance project of the U.S. Geological Survey: U.S. Geological Survey Open-File Report 90-162.

Maloney, T.J., Lutke, A.S., Krizman, T.L., 1993, Quality assurance for routine water analysis in the laboratories of the U.S. Geological Survey for water year 1990: U.S. Geological Survey Water-Resources Investigations Report 93-4081, $145 \mathrm{p}$.

Marston, R.A., Pochop, L.O., Kerr, G.L., Varujka, M.L., and Veryzer, D.J., 1991, Recent glacier changes in the Wind River Range, Wyoming: Physical Geography, v. 12, p 115-123.

Muller, R.A., 1977, Radioisotope dating with a cyclotron: Science, v. 196, n. 4289, p. 489-494.

Naftz, D.L., Rice, J.A., and Ranville, J.R., 1991, Glacial ice composition: A potential long-term record of the chemistry of atmospheric depostion, Wind River Range, Wyoming: Water Resources Research, vol. 27, no. 6, p. 1231-1238.

Naftz, D.L., Klusman, R.W., Michel, R.L., Schuster, P.F., Reddy, M.M., Taylor, H.E., Yanosky, T.M., and McConnaughey, E.A., 1996, Little Ice Age evidence from a south-central North American ice core, USA: Arctic and Alpine Research, v. 28, no. 1, p. 35-41.

Parrington, J.R., Knox, H.D., Breneman, S.L., Baum, E.M., and Feiner, F., 1996, Nuclides and Isotopes, Chart of the Nuclides, 15th Edition. General Electric Co., 64 p.

Robertson, J.B., Schoen, R., and Barraclough, J.T., 1974, The influence of liquid waste disposal on the geochemistry of water at the National Reactor Testing Station, Idaho-1952-1970: U.S. Geological Survey Open-File Report IDO-22053, $231 \mathrm{p}$.

Synal, H.A., Beer, J., Bonani, G., Suter, M., and Woelfli, W., 1991, Atmospheric transport of bomb-produced ${ }^{36} \mathrm{Cl}$ : Nuclear Instruments and Methods in Physics Research, vol. B52, p. 483-488.

Vogt, S., Elmore, D., and Fritz, S., 1994, ${ }^{36} \mathrm{Cl}$ in shallow, perched aquifers from central Indiana: Nuclear Instruments and Methods in Physics Research, vol. B52, p. 65-69

Whitehead, R.L., 1992, Geohydrologic framework of the Snake River Plain regional aquifer system, Idaho and eastern Oregon: U.S. Geological Survey Professional Paper 1408-B, 32 p., 6 pls.

Wood, W.W., and Low, W.H., 1988, Solute Geochemistry of the Snake River Plain Regional Aquifer System, Idaho and Eastern Oregon: U.S. Geological Survey Professional Paper 1408-D, 79 p. 